\title{
The Paradigm Shift of Political Science from Being "Change-oriented" to "Governance-oriented:" A Perspective on History of Political Science
}

\section{Guangbin Yang ${ }^{1}$}

Received: 13 August 2021 / Accepted: 19 August 2021 / Published online: 4 September 2021

(C) The Author(s) 2021

\begin{abstract}
The history of political philosophy serves as a valuable resource for the current research paradigms in political science. In comparative terms, the paradigm of Western research is essentially "change-oriented" and tends to shift constantly with its evolving thoughts. Due to the influence of bourgeois revolutions around the world, contemporary politics has transpired as the synopsis of governance of the established order. As the "governing strategies" of the established order encounter multiple social crises, the Marxist political science or Marxism has emerged as the naturally preferred alternative research paradigm. During the Cold War period, such governing strategies were adopted as universal values in Western political science, effectuating the prediction of "the end of the history." After the launch of the reform and opening-up campaign, "change-oriented" liberal democracy became an instrumental paradigm for Chinese political science. However, as the contemporary world order disfavored this paradigm, Chinese scholars shifted their research focus to developing an independent discourse power in democracy and governance, as well as prioritizing state governance as their primary research paradigm and methodology. Thus, political science is expected to resume its common sense nearly after a century of political chaos.
\end{abstract}

Keywords History of the discipline of political science $\cdot$ Liberal democracy . Marxist political science $\cdot$ Research paradigm $\cdot$ State governance

Guangbin Yang

yanggw@ruc.edu.cn

1 Yang Guangbin, Distinguished Professor of Political Science and Dean of School International Studies, Renmin University of China, Beijing, China 


\section{Introduction}

The history of political philosophy acts as a constructive resource for the study of political science. As political science followed diverse paths in the West and the East, these regions cultivated a political ideology with disparate characteristics. The Western history of political ideology with its ever-evolving social reforms and fluctuating beliefs has, in turn, induced a great amount of changes to the political community in general. Particularly with respect to the theocratic medieval Europe, Benedict Anderson introduced the idea of "Imagined Communities" in his book of the same name, which is pertinent to the Europe that existed before the formation of nation-states. As for the emergence of nation-states, such as in Germany, it was a cumulative product of the intellectuals' "imagination" during the Sturm und Drang movement, and consequently, the German ideology has been constantly shifting ever since. Contrarily, the political ideology in China has more or less remained unaltered in essence, since it is endowed with an uninterrupted historical belief system and the people-oriented philosophy has dominated this country for a solid 2000 years. The reason could be attributed to the fact that China subsists as a unified country with a robust bureaucratic system, a patriarchal society, and an uninterrupted language and written system. The presence of such fundamental yet vital elements of civilization functioning has allowed China to emerge as an uninterrupted civilization (Yang 2016a, b, c, d). Nonetheless, even with the Western history of political ideology and political science being "change-oriented" in "imagination," "changes" tend to be cyclical. For example, in the hundreds of years following the bourgeois revolution in Europe, the universal primary mission of political science was to establish the legitimacy of capitalist politics and its functioning mechanism, i.e., to seek "governance" after "change." Due to the need to prevail in the "Cold War," various theories on certain political concepts, such as Western politics, were devised as "universal values" and implemented in a way to change the opponents and even amend the politics of all major non-Western countries. For this reason, the field of political science that addressed "governance", once again became a "change-oriented" discipline, or at least a field that seeks to reform other countries. Noticeably, such research no longer remains merely academic but has become a pivotal part of political disputes and inter-state politics. As the utility of political science was tested to its extreme in terms of political practices, there was a significant change in political thoughts and practices in socialist countries as well as in several nonWestern countries, resulting in the collapse of the Soviet Union, the third wave of democracy, and subsequent Arab Spring and Ukrainian crisis.

China has never functioned independent of world politics. Long before the founding of the People's Republic of China (PRC), Chinese scholars had been interpreting the policies of Western powers, so as to reform China in accordance with the Western model. But eventually, Marxism prevailed. Post the founding of the PRC, class conflicts gave rise to the disastrous Cultural Revolution. The subsequent reform and opening-up campaign was actually the second attempt undertaken by China to learn from other countries. But this time, China pursued the 
theories and institutions based on liberal democracy that advocate both "liberty" as well as "democracy." Even though it was essentially an attempt to reform itself in the wake of the basic theories of Western politics, China, unlike several other non-Western countries, did not change itself, rather it figured out its own path of transformation and also developed concepts and prominent doctrines, like the "Chinese model", "Chinese path", or "resilient authoritarianism" that have long fascinated the West. China's achievements must be interpreted positively. Theories that fail to explain the Chinese approach cannot be considered worthy social science theories. They must directly address the achievements based on Chinese history, culture, and practices. Such achievements ought to be conceptualized, theorized, and then developed into a paradigm. The Chinese approach is explainable via various dimensions, but it principally implies one vital logic: accepting and integrating the achievements of other world civilizations with the 2000-yearold people-oriented philosophy centered on "political stability." Hence, "political stability" is a core concept and an instrumental paradigm that needs to be appreciated under the contemporary political science based on Chinese practices.

This review commences with a summary of the "changeability" of Western political ideology and the ascertained reasons behind it. This is followed by an elaboration on how the Western political science transformed itself from a philosophical system discussing the legitimacy of Western democracy to one that seeks to "change" the politics of other countries, and also how the "change" paradigm was created. The subsequent section is an investigation into the advantages and disadvantages of "change-oriented" Chinese political science in the past century. Lastly, the summary entails the main tendencies of Chinese political studies: establishmentoriented state governance studies form the mainstream Chinese political science.

To deeply explore the realm of state governance, we need to reconsider the concept of society as the state that technically stems from society only. However, contemporary political science largely deals with only a singular ideology on society: "civil society." In this article, it is believed that "civil society," as a concept, has not proven to be consistent with any society. Thus, the governance theories based on "civil society" may seem pleasing to hear, but are hardly pragmatic.

\section{Chinese and Western Histories of Political Ideology: "Stability" and "Changeability"}

Reasonably, one of the major differences between the Chinese and the Western history of political ideology appears to be that the former has been rather "stable" and the latter quite "changeable." The conventional Chinese society and ideology tend to be so extraordinarily stable that G. W. F. Hegel once said that "China has no history" (Hegel 2009). However, to me, such stability does not particularly imply that China is without history, but rather, it means that China's history is uninterrupted. Westerners, customarily, are so accustomed to a changeable history that they deem such continuity rather as a stagnation (Wong 2016). This novel perspective is quite vital because it deals with our approach to address a fundamental subject: "history". "No history" and "an uninterrupted history" are fundamentally different factors. 
For those who believe the former, China's "unchangeability" is basically considered as an indicator of backwardness; whereas for the ones who believe the latter, China is endowed with a distinctive history as compared to the Western one, right from the beginning and that the difference lies in China's "prematurity" or precocious modernity. As said by Professor R. Bin Wong, "In 1400, as if in stark contrast, Europe was disorganized politically as many small political units (including citystates, dioceses, principalities, and kingdoms) coexisted, while China was already a vast empire without any aristocracy, religious institutions, or political conventions that resembled those of Europe" (ibid.). In other words, as per European standards, China was already a modern society. Since it already exhibited various characteristics of modernity, why would China's history change? Once again, as per European standards, such as those of Leopold von Ranke, the German founder of modern source-based history, Europe in no manner exhibited any characteristics of "modernity" until the late 1400s-1500s when nation-states, bureaucratic politics, secularized political affairs, and standing armies emerged (Potter 1999). Other phenomena of modernity included personal freedom embodied by the Renaissance.

If such are the features of modernity, the political system in pre-Qin China was indeed already modern going by the Western standards. The most remarkable example is their non-hereditary bureaucratic system and system of prefectures and counties. As far as freedom is considered, China has been an atheist nation right since the pre-Qin era. As Confucius once said, "Respect supernatural beings, but stay away from them." Atheism should be a prerequisite for freedom. Personal freedom was never a political issue in the Western Han Dynasty when the Huang-Lao philosophy was dominant. It would not be wrong to say that they were the cradle of liberalism. As pronounced by the Austrian school of economics, "The Taoists were the world's first libertarians, who believed in virtually no interference by the state in economy or society" (Rothbard 2016). Therefore, unlike Westerners, the Chinese did not acquire the most elemental prerequisite for human liberation and freedom through the enlightenment after a thousand-year theocracy. Due to the incredible "uninterrupted" Chinese history, the people-oriented Confucianism that has been ruling the country for more than 2000 years still lies at the core of China's political ideology.

Furthermore, I believe that it is highly imperative for modern politics to answer a fundamental existential question: Why do modern states exist? To answer that, we must return to the ontology of state modernity. Although Aristotle came up with the notion of "city-state" for the "highest good," modern states appeared rather late in the West. The earliest example was after the signing of the Peace of Westphalia treaties, which was a result of the "drastic changes" induced over 2000 years. China, on the other hand, was established as a unified feudal state in the Zhou dynasty by that time and already presumed that "people are the foundation of the state." In the European history, whether it is a city-state, an empire, or a feudal manor, how many of these communities shared the same philosophy? According to The History of Government from the Earliest Times by S. E. Finer, rulers of almost all the states, except China, imposed taxes on people for reinforcing their own power, including keeping an imperial army and endorsing the maintenance of the imperial court. Hence, there is a need to reconsider the nature of the ancient history of China, i.e., its national history, and comprehensively compare it with the Western standards of modernity. 
Western political ideology, on the other hand, tends to change constantly. Several of their historical doctrines are nowhere to be found in the present-day Western societies and are considered significant only as a part of the history of human ideology or as a subject of historical study. The logic behind this is quite simple: thoughts are subject to change with time. As the Western world underwent multiple revolutionary institutional reforms, novel ideas came into existence, and the old ones were subverted and discarded. Beliefs are the cumulative product of the social institutions in a given period of time, which implies that different social institutions (let alone different civilizations) can indeed give birth to different ideologies. For the sake of discussion, the following sections revolve around the Western history of political ideology and briefly discuss the most representative ideas on the topic of regime from each era.

The concept of regime was introduced in the era of city-states and empires. Considering the ancient Greek era of city-states, the most eminent figures are Plato and Aristotle. Both were influenced by what happened to Socrates and disapproved of democratic politics. In response to that certain event, Plato came up with the notion of "philosopher king", which is analogous to the concept of present-day ideologist. Aristotle, on the other hand, shared more similarities with the contemporary political scientists. He did a comparative study of 158 city-states and classified their regimes. Consequently, Aristotle left a more influential legacy than Plato, although certain conservatives, such as the Straussians and their followers, still consider the "philosopher king" as an ideal concept. According to Aristotle, city-states existed on a natural basis. Men and women form families, families form villages, and villages form city-states. Thus, city state is understood as a natural form of human union. In a naturally existing city-state, "man is by nature a political (city) animal." In essence, city-states exist before individuals, which signifies that the collective body matters more than its members. This is because once the collective body is eradicated, its members cease to exist as well, just like the limbs of a destroyed body. To most Westerners today, this naturalistic vision of regime, like that of Plato, sounds somewhat totalitarian. Nevertheless, as the world's first known political scientist, Aristotle, based on an inclusive classification of demographic structure, professions, and labor division, established the corresponding types of regimes, i.e., the recognized six forms of government, including three true forms and three defective and perverted forms. Such classification encompasses the mixed form of government"republic"- as the ideal one. According to him, changes in demography, professions, and labor division will inevitably produce relevant changes in the associated regime.

During the Hellenistic period, the Romans built their city-states into an empire whose population once peaked at eight to ten million. However, no innovation took birth on their part of the understanding of regimes or governance, apart from Polybius' version of the kyklos: monarchy-tyranny, aristocracy-oligarchy-democracy-ochlocracy-monarchy. This version appears to be a typical biological viewpoint on regimes, since it considers the rise and fall of a regime as an inevitable naturalist process that leads from birth and growth to prosperity and decline.

Understandably, Chinese and Western schools of political ideology in the same eras exhibited inherent differences and these disparities were a proof that China 
already possessed what the Westerners called a "modern" regime. First, considering the concept of freedom. From the naturalist viewpoint, the regime is a holistic concept. In ancient times, the contemporary principles such as personal liberty and rights were absent even in democratic states, let alone in Greece and Rome where the economic system itself was based on slavery or in medieval Europe where people were enslaved to theocracy for 1000 years. Hence, it only seems reasonable for the Europeans to yearn for personal liberation. In relative terms, China neither had institutional nor spiritual slavery in the same period. From the pre-Qin era to the early Han dynasty, the Han people under the passive Taoist governance model were already bestowed with the value of personal liberty that Greeks and Romans could only long for. As may be noted, the right to personal liberty that the Chinese people possessed was inaccessible to the Westerners until the Renaissance movement came about 2000 years later.

Second, talking about regime and governance. The second major difference between pre-Qin, Qin, and Han China, and Greece-Rome tends to be that the latter were more concerned about the internal order of their small community, whereas the former had an inherent pursuit of unity: there were 158 city-states in just Aristotle's Greece, which led to the advanced theories on the intricate concept of regime; China, on the other hand, has by and large been a unified nation and periods with multiple states in its history are defined as exceptions. The form of government suitable for a unified country is, without any doubt, monarchy. The only question is who the ruler should be and how they should rule. Thus, ancient Chinese philosophers prioritized the topic of "stable governance". Back in the 8th or seventh century BCE, in the Qi state under Guan Zhong's rule, the modern political economics was already implemented, and it was later termed as "policy-making theory." Relatively speaking, virtually no theory of governance existed in Greece-Rome, apart from Aristotle's observation of labor division (not exactly a theory). Since then, until the seventeenth century, Western economics had been stagnating. As the Austrian school of economics addressed in their research, ancient Greece "was essentially a desert of economic thought" and "economic theorizing collapsed right after the death of Aristotle, and later Hellenistic and Roman epochs were virtually devoid of economic thought" (Rothbard 2016). As for the European school of political economics, i.e., classical political economics, it materialized 2000 years later than its counterpart in China.

Thirdly, talking about how to organize a state. Ancient Greek city-states were rather small, so their form of government was equivalent to the form of state. In Roman times, their territory expanded vastly, but there existed no all-inclusive system, as discussed in modern theories on central-local relations, to facilitate the organization of the empire. What they possessed was at the most an individualized agency system. In pre-Qin China, on the other hand, some lesser states already functioned with the system of prefectures and counties, which represented a revolution on the primitive ruling system based on kinship, replacing it with the one based on military exploits. In this sense, no real form of state structure existed in the West until the federal system appeared in the United States after the War of Independence. China was way ahead of the West, by over 2000 years, in adopting such a just system. 
The concept of regime in the era of theocracy. As the barbarians destroyed the Roman Empire, Europe stepped into the Middle Ages (the fifth-fifteenth centuries), the first half of which was an era of theocracy when religious authority and the royal power were irreconcilable with each other (dualist politics).

With the brutal assault by the barbarians of Rome, the budding Christian religion suffered a major blow. It was considered a punishment of the religion, which indicated that it needed re-interpretation. Based on Neo-Platonism that seeks to save people's souls, Augustine of Hippo coined the notions of "the city of God" and "the city of man." The former, represented by Catholicity, eventually prevailed over the latter, represented by Rome, the new Babylon. To reach the city of God on the other side, Augustine invented the notion of "original sin" and attributed to it all the human depravities and evil. Additionally, he pronounced that people cannot purify themselves of this sin and could be cleansed only by converting to Catholicity. Therefore, religious authority was stronger and higher than the royal power and theocracy was higher than monarchy. Augustine rephrased classical secular politics into theocracy. In the latter half of the Middle Ages, i.e., the 11th-thirteenth centuries, royal power grew in their contention for superiority, so did the bourgeoisie in cities, shaking the belief of human subjection to divinity. To save people's faith in theocracy, Thomas Aquinas introduced Aristotle's naturalist ideas into it to explore new interpretations for the social structure that had been fundamentally changed. He believed that nature was also a Godcreated order. In other words, the growing royal power and the thriving bourgeoisie were the new order under religious authority.

The concept of regime in the absolutist states (early nation-states). The subsequent century of the Middle Ages, termed as the era of "absolutist states" in the West, witnessed a decline in religious authority, and the European political history primarily revolved around "contention" between the royal power and the religious authority, as well as the feudal aristocrats and the bourgeoisie (merchants).

The rise of absolutist states was by and large related to feudal economy, the advent of which was somewhat accidental. Nearly a century-long 'Black Death' that killed one-fourth of the European population inflicted a hefty blow on the church-centered regime, effectuating the feudal economy that entailed personal liberty: Serfs were liberated in an effort to slash the gap in labor work, and they chose to work for wellpaying feudal manors. The expanding faction of feudal manors evolved into states identical to the city-states in Ancient Greece, whilst the conflict between them generated certain representative political communities based on their national identity, i.e., the prototype of early nation-states. Due to the perpetual existence of the Church in the regime, Thomas Aquinas reformed Aristotle's theories into a theocracy that could be conducive to humanity, i.e., "divine right of kings": kings' rule of states being just as legitimate as God's rule of the universe. It presented European monarchy with an additional source of legitimacy along with the Church's recognition. The contention between the Church and the feudal lords gave rise to early nation-states, which were termed as "absolutist states" since such communities held only limited power and hence competed for absolute power as one of their major objectives. At the end of the Middle Ages, the background was as such that it gave birth to Machiavelli's The Prince and Jean Bodin's 'theory of sovereignty'. 
The concept of regime in the era of capitalism. The period of Renaissance sought to revive Cicero's republicanism and Aristotle's naturalism, creating favorable conditions for the advent of natural law, natural rights, social contract, and several other similar thoughts. At this point, royal power, religious authority, and aristocracy were all at the brink of losing their philosophical and theoretical legitimacy, which essentially produced a capitalist regime. Capitalism primarily possesses two "matrices." One is the well-known feudalism, called the "social matrix", and the other is the often-neglected Christianity, called the "civilization matrix". The capitalist political system is, in fact, the re-embodiment of Christianity in modern politics, or the Church of politics (Yang 2016a, b, c, d). Hence, the core of the capitalist regime is embedded in what John Locke called the natural rights to life, property, and liberty, or Locke's liberalism, demonstrated as parliamentary sovereignty in his political philosophy work-Two Treatises of Government.

The capitalist regime seems to follow the "spontaneous order". During the rise of the bourgeoisie, David Hume posited the theory of automatic adjustment for balance-of-payments disequilibria and Adam Smith postulated the theory of free trade based on the former. Both represent classical liberal schools of ideology on capitalist market economy. Predicated on this groundwork, the capitalist regime emerged following the political development of over two hundred years. In the mid-eighteenth century, Montesquieu proposed the balance of power based on England's regime, which was later employed as a blueprint for the formulation of the United States' republican system. The United States, in addition to a written constitution, devised the contemporary political party system in 1800, thereby acknowledging the representative role of the political parties in the election machine. In the mid and late nineteenth century, John Stuart Mill hypothesized his theory on representative government that recognized parliamentary sovereignty and Walter Bagehot postulated his comparative political theories on parliamentarism and presidentialism. In the early twentieth century, Woodrow Wilson theorized his hypotheses on the United States' congressional government.

The growth of the capitalist government seems to corroborate the "spontaneous order" theory under natural law, or democracy under the control of market economy-societal structure differentiation-representative democracy-multi-party system-competitive election-and capital-based democracy/capital power. "Spontaneous order" inevitably appears as a conducive logic for the strong that would engender a situation where the strong would get even stronger and the weak even weaker. For this reason, the capitalist democracy is essentially deemed to be capitalbased democracy. When John Locke called for the protection of property right, he was a slave trader; the whites on arriving at the New World tried to drive out the indigenous population and attributed their legitimacy to Locke who suggested that since labor produces wealth, the wealth did not belong to the indigenous populaces who were not working, but principally to the white. This is the true logic behind the spontaneous order theory. Democracy is supposed to be for all, but once it is held captive by capital, social inequality becomes inevitable and the socialist movement necessary.

The concept of regime in the socialist movement. Socialism displays a prolonged history, but the self-conscious socialist movements materialized only around the 
mid-19th century when the Second Industrial Revolution attained its climax. As socialism strives for equality as its most fundamental demand, socialist democracy is pretty much founded on the concept of society than on capital. Classical authors like Karl Marx and those who followed him, including the social-democratic Marxists Eduard Bernstein, Karl Johann Kautsky from Germany, and the Fabian Society from England, are all deemed to be eminent socialists. In a political institution primarily governed by capital, the maximum social-democratic activists could accomplish was to resort to reformism and fiddle with the status quo without fundamentally changing the capitalist political system. That was where the revolutionary Marxism drew a line with reformist Marxism.

On the whole, our research on the evolution of European ideologies has led to the following findings:

First and foremost, generally speaking, "change" is a norm in the history of European ideology as institutional changes produce a variety of philosophical schools on the matter of regime and Westerners have a growing propensity towards "change". Pertinent to other civilizations, Europe underwent frequent changes in their regime, which, in a sense, was a result of the model "idea-created world": European communities were all "imaginary communities", such as the concept of "city of God" coined by Augustine that gave rise to the nearly thousand year-long theocratic political system; whereas in the subsequent centuries of the Middle Ages, "city of God" was replaced by the more secular concept of "divine right of kings" that served monarchy. It can be argued that the early state of the Western society gave rise to their initial theories which, in turn, contributed to the changes to their social reality. Therefore, the relationship between changes to their philosophy and those to their institutions have more or less been a chicken-and-egg conundrum, where it seems impossible to establish the actual causality or a stable order. None of the other civilizations have encountered such a hindrance.

Second, in terms of research methodology, the 2,000 year-long political history of Europe is rife with drastic social and political changes. If not approached from the perspective of comparative-historical studies, achieving any breakthrough concerning the research on the Western history of political ideology would not be possible.

Third, it must be recognized that although "change" is a norm in the West, the novel ideology stemming from such changes usually remains dominating for at least several centuries. For example, the naturalist view on the regime was prevailing in the entire Greece-Rome era; the concept of "city of God" governed Europe for nearly 1000 years; the belief in "divine right of kings" persisted through the latter half of the Middle Ages; and the capitalist regime following sovereignty survived nearly 400 years. Socialism, created along with capitalism, currently holds a history of 200 plus years, and the social democracy that it advocates ought to be the universal future direction for humanity. Therefore, such a course of history establishes that the central objective of ideological changes is to serve "governance"; otherwise, none of the ideas would prevail for hundreds of years after the revolution.

Fourth, even the "changes" in the West appeared rather continuous in the course of history. When the naturalist regime fell into crisis, people expected that Christianity could save them and thus theocracy reigned over Europe. However, theocracy was not only beneficial to the Church, but also to secular 
governments, i.e., the sovereign states that emerged following the "divine right of kings." Such was the result of the Church's modification of Aristotle's naturalism. By virtue of such modification, naturalism, after being disfavored for nearly 1000 years, was revived and progressed into the contemporary concepts of natural law and natural rights, bringing about capitalism, which is essentially based on the innate rights of man. The inequality of capitalism led to socialism and socialist movements seeking to restore equality which, in a sense, is also a natural right. Therefore, the European history of ideology revolves around naturalism and natural law.

Fifth, each political change entails an inherent historical logic, which truly appears to be a fundamental social condition. Theories on these conditions for a certain regime tend to be the core of the European philosophical school on regime. For example, Aristotle never overlooked the various conditions for each regime in his analyses. In contemporary times, as the world experienced better connectivity with enhanced navigation technologies, philosophers comprehended the differences between nations and began to emphasize the national characteristics of each regime. For example, Montesquieu wrote extensively about public morality in The Spirit of the Laws; John Stuart Mill wrote in Considerations on Representative Government that representative government, although deemed as the best form of government, is not an equal fit for all nations. In recent times, in his The Law of Peoples, John Rawls, unlike the arrogant liberals believing in universal values, reconstructed the regime standards in non-Western societies that do not satisfy the social conditions of the West, indicating that the legitimacy standards for Western regimes cannot be implemented to evaluate non-Western regimes. Every regime progresses in a society and common sense suggests that social conditions are both valuable and necessary. However, scholars and politicians obsessed with a certain institution tend to overlook this wisdom and blindly seek "changes." Such an approach often proves counterproductive.

\section{The Pro-establishment yet Revolutionary Western Political Science: From Demonstrating their Own Political Legitimacy to Changing the Regimes of Other Countries}

In the latter half of the nineteenth century, the history of Western political ideology evolved into a proper discipline: political science. Around the inception of the discipline, its primary research was based on the status quo of existing institutions and centered around related issues, rather than the belief in such institutions. Back then, as Western countries were riddled with political issues, there existed critical thinkers that held vastly diverse political views, such as Karl Marx and Carl Schmitt. In the twentieth century, global political science became rather ideological, a situation not so different from that of the Middle Ages when theocracy reigned. Consequently, theories that illustrated the legitimacy of their own regime were turned into a tool for modifying other countries' political systems. 


\subsection{Pro-establishment: Political Theories on the Legitimacy of Current Political Institutions}

Following the advent of European nation-states and their growth over hundreds of years, Western political science transformed into the political science that we know today only in the latter half of the nineteenth century. Based on its key components, its general framework can be summed up as follows:

The theory of the state. Political sciences have long been known as "a discipline about the state" as their initial objective was to facilitate the creation of modern states. Modern times in the West started with the period of Renaissance. The most paramount achievement in political science during that period was Machiavelli's The Prince (far more influential than Discourses on Livy and his other works). The book focuses on how to unify the Apennine Peninsula fragmented by rivaling warlords and constant conflicts and necessitates an authoritarian monarchy with both the characteristics of a lion and a fox. He was thus believed to be the first one to separate ethics from politics. These views from continental Europe led to Thomas Hobbes' Leviathan that demanded the same order in the English Revolution. He devised a new sovereignty construction model. To Hobbes, any order is better than no order. This view exhibited an extensive impact and Samuel P. Huntington's conservatism is evidently connected to it. Although they perceived the establishment of an order as their basic demand, Machiavelli and Hobbes were not opposed to personal liberation and freedom. Therefore, they are regarded as forefathers of liberalism. After the development of over hundreds of years, the science of state attained its climax with Max Weber. He postulated the famous conception of state as the monopoly on violence, based on which territory, population, government, and army are proposed as the four components of a modern state.

The theory on rights (constitutionalism). Machiavelli and Hobbes failed to reinforce the sovereignty of monarchy. On the contrary, they contributed to the rise of individualism and the development of liberal constitutionalism: Liberty is associated with personal rights while the constitution restricts state power. The forefather of liberal constitutionalism, without any doubt, is John Locke. His major claim in Two Treatises of Government (vol. II) was summed up as possessive individualism by C. B. Macpherson and interpreted as privilege of the few, or oligarchy. If Locke's ideas laid the theoretical foundation for the capitalist rule, the Scottish and French Enlightenment further strengthened the ruling model. The Scottish Enlightenment, headed by David Hume and Adam Smith, generated more systematical theories on political philosophy and economics for the emerging bourgeoisie, whereas the French Enlightenment furnished the ethical legitimacy for their rule. Only in this manner can the "property right" be restructured from a simple "right" into a statecontrolling "power": "Modern state is but a committee for managing the common affairs of the whole bourgeoisie" (Karl Marx).

Theories on government (representative system). Both, Locke's "parliamentary sovereignty" and the principle of "balance of power" advocated by Montesquieu and the founding fathers of the United States appear as forms of representative government and of capitalist rule in essence. Fundamentally, the representative system can be realized in a multi-party or electoral form, which applies to both the 
parliamentary as well as the presidential government; in a competitive electoral system, political parties as well as the politicians are bound to be controlled by capital, hence, liberal constitutionalism ends up serving the class rule.

Political science in the era of old institutionalism (late 1800s-1945) analyzed all the aforementioned political systems and their corresponding constitutions and laws. The basic premise of the legalistic tradition in political science is the legitimacy (as defined by Weber) of legal state, government, political party, and other political organizations. Hence, political science in this era remained "pro-establishment" and its primary objective was to establish the rationality and sanctity of the existing institutions. Nonetheless, the capitalist regime did not become more respected or followed due to their "pro-establishment" stance. Instead, it happened to be increasingly precarious.

\subsection{Critical Political Science}

As mentioned above, the political practices and institutional changes in the Western countries tend to abide by the "spontaneous order" logic, but this claim does not take into account the fact that Europe was a bully for the underprivileged countries in its modern history. Such an ostrich policy never tends to be conducive for the resolution of any issue. Rather, it can only convert the issue into a crisis. The source of crisis usually lies in the representative democracy's failure to deliver what it is supposed to do. The oligarchic representative democracy faces two insoluble issues: capital's control over public power and the dual predicament of the logic of democratic republic.

The best-known political theory on the former issue is Marx's social criticism. His materialist conception of history is an indispensable method for evaluating capitalist society. Subsequent research on democracy and inequality is all based on Marx's major proposition: The tension between political equality, represented by universal suffrage and economic inequality would inevitably lead to schizophrenic reactions from members of the capitalist society and the only way to the "realm of freedom" is to launch a proletarian revolution and build a proletarian republic like the Paris Commune. Though the Paris Commune turned out to be a failure, Marx's theories on revolution forged a new world, a socialist bloc in the imperialistic world system. Encouraged by the socialist revolutions, national liberation movements terminated the colonial system, at least politically.

The second issue manifests itself in two ways. One is Alexis de Tocqueville's "tyranny of the majority." Conservatives like Edmund Burke, Italian elitists like Gaetano Mosca, and Gustave Le Bon from France held similar views. The other one is that the "public" do not have what "democracy" requires of them. Carl Schmitt (2004), a prestigious German scholar of constitutional studies, reckons that the premise of democracy is "homogeneity." He said, "democracy requires, therefore, first homogeneity and second - if the need arises_elimination or eradication of heterogeneity." This is the true form of democracy. Naturally, the Weimar Republic that introduced representative democracy despite unfavorable conditions was not able to resolve the divisive movements and conflicts brought about by the heterogeneity. 
Consequently, Hitler came to power. Within this framework, all the scholars that can recognize the complexity of "the public" tend to review mass democracy in specific social and economic conditions.

In fact, the British democracy was based on elections within the same "race"; the American democracy did not grant the indigenous populaces the right to vote and launched genocides against them, which later ensued as a research case for Hitler in his genocide against the Jewish people (Mann 2015). Seymour M. Lipset (2011), whose theories are based on lessons from the Weimar Republic and turbulent French politics, considers that electoral democracy should be the basis of the legitimacy of Western politics and emphasized "cultural homogeneity" as a prerequisite even during the Cold War. In all the Western countries, successful and fruitful democracy was born within a homogeneous culture and mass elections did not take place until their economic development reached a certain level. For example, in England, the first constitutional reform was launched in 1832, 150 years later than the end of the Glorious Revolution; in the United States, the suffrage did not cover the majority of the white people until the 1830s, 60 years into its founding, and did not cover people of all ethnicities until the 1960s, nearly two centuries after its founding.

Nevertheless, since the beginning of the WWII, especially after the Cold War, Western countries had been introducing certain concepts that they themselves never put into practice to the institutions of non-Western countries: Forced electoral democracy, or partisan democracy, in economically underdeveloped and culturally heterogeneous societies without any tradition in the rule of law. Friedman (2001), an arrogant columnist of New York Times, likes to point his fingers and advocates that the solution to terrorism and conflicts in the Middle East is to establish "multi-racial, diversified, and free-market democracy". The United Kingdom and the United States have never practiced such a democracy under such social conditions. Moreover, they have been advocating a denationalized free-market economy that they themselves had discarded 100 years ago. Some scholars pointed out, "the free-market economy forced on non-Western countries, comprised of both liberal capitalism and universal suffrage, is a solution that none of the Western countries have ever put into use in their history" (Chua 2014).

Simply put, a representative democracy itself has been the root cause of all the problems in the West and it is lucidly foreseeable what would happen if this structurally defective solution is introduced in non-Western societies under totally different social conditions. The central question on this subject matter is why the "proestablishment" Western political science is so steadfast in reforming other countries with a problematic solution.

\subsection{Revolutionary-pretending Western Political Science: From “Modernization" to "Democratization"}

The primary mission of political science has always been to actualize "the highest good" or "the most possible good", that is, to establish good governance in a country. However, with the outbreak of the Cold War, world politics seemed to have returned to a theocracy-like state typical of the Middle Ages when Europe launched 
seven crusades to eliminate the pagan Islam and convert it to Christianity. During the Cold War, the Soviet Union launched a "world revolution" to disseminate Soviet-style communism while the United States tried to create a "free world" in the name of "liberty and democracy." In the end, the United States "won the white war". They won because of their ideological strategies and tactics. Ideology was the "main battlefield" of the Cold War (Yang 2000). Thus, right since the beginning, the United States has been running with its ideological machine at full power. As social sciences emerged as the most vital part of the war, their "neutrality" and "objectiveness" as "sciences" played a fundamental role. However, such a role did not change the nature of the Cold War. On the contrary, the ideological war changed the nature of social sciences and rendered it nearly entirely "political." Many concepts appearing persuasive for the ideology of the general population today, such as freedom, democracy, constitutionalism, civil society, market economy, and legitimacy, and mainstream methodologies, such as rational choice and institutionalism, were all born in the era of Cold War. Therefore, although Western thoughts have a prolonged history, the ones that appear directly influential even today were all provided by social scientists in the Cold War, while the classical schools of ideology, including those of Plato and Aristotle, are only utilized as a backdrop.

Relatively speaking, the classical ideologies in China have never fallen out of favor and are ubiquitous in people's life to this day. In this sense, Western civilization has been discontinuous with rifts between the medieval Christian civilization and the classical civilization (which is a well-known fact although the former takes the latter as one of its resources) and between the modern ideologies and the Cold War mindset. In other words, in terms of political theories, classical ideologies only act as a backdrop for the ideologies during the Cold War, or liberal oligarchy in modern times. Furthermore, they have been modified into political theories on liberal democracy. Similarly, ideologies and institutions criticized by Karl Marx, Carl Schmitt, and several others have been lauded for their role in self-defense and transformation of various other countries. Noticeably, while their political theories have been discontinuous, their economic foundation has not gone through any solid fundamental change. Typical capitalism has persisted for 500 years even though the agrarian capitalism in the 1500-1600 s evolved into industrial capitalism in the 1700-1800s and later into financial capitalism in the twentieth century.

As for the relationship between the Cold War and the development of modern social sciences in the United States, authoritative research has established that the US National Security Council of CIA ordered to develop social sciences that centered on liberty as a "mind game" (Saunders 2002). Thereby, social sciences became a "propaganda war" aiming to influence the thinking and behavioral patterns of certain groups of people. ${ }^{1}$

\footnotetext{
1 Westerners often believe that their social sciences are "sciences" while the Chinese ideology sounds much like "propaganda." What they do not know is that social sciences are part of a "propaganda war" of the United States as specified in official documents. The "propaganda war" is the behavioral science that developed during the WWII, founded by Harold Dwight Lasswell, a political scientist.
} 


\subsubsection{The Structural Functionalist Paradigm for Modernization Studies}

This propaganda war is spearheaded by the American political scientists. In 1953, the Committee on Comparative Politics was founded under the US Social Science Research Council (SSRC) with the aim of fulfilling the council's mission to promote "behavioral research". According to the report in the SSRC's Interuniversity Research Seminar on Comparative Politics, in the past 50 years, "comparative politics in the field of political science while suffering from all the ambiguities and methodological inadequacies of the field in general, has been ill-defined."(Macridis and Cox 1953). As a result, as Almond suggested, it is imperative to discover alternative terms, replacing, for example, "state" with "political system", "power" with "function", "duty" with "role", "institution" with "structure", and "public opinion" and "citizenship training" with "political culture" and "political socialization", respectively. He wrote, "the urge towards a new conceptual unity (or paradigmauthor's note) is suggested when we compare new terms with the old" (Almond, 2012).

By 1959, the "conceptual unity" had been constructed with expected results: Studying "foreign political systems" or non-Western state politics, with one single paradigm - structural functionalism. This "conceptual unity" is deemed to be Almond's structural functionalism. The seven elements of structural functionalism (inputs: recruitment, interest articulation, interest aggregation, and political communication; outputs: rule making, rule application, and rule adjudication) befell as common sense and scholars like Almond believed that all the political systems should possess these seven functions that could be explained within this framework and domain. Perceptibly, in The Politics of the Developing Areas, he wrote that politics of non-Western countries, including southeast and south Asian, Sub-Saharan African, Near Eastern, and Latin American countries, can be elucidated using the "conceptual unity" in structural functionalism.

How rigid can an ideology be? The Community of International Social Scientists was flabbergasted when the Committee on Comparative Politics tried to explain the political issues of all the regions and countries with a single paradigm. This notion of "conceptual unity" was persuasive over American political science for nearly 30 years from the 1950s to the 1970s, when the structural functionalism dominated comparative political studies in the United States. In other words, "modernization" as a research subject of American social sciences (and even history) is based on the inherent logic of "development brings in democracy", which is the process of modernization. This logic is backed by the structural functionalist paradigm that presumes that modernization will surely arrive as long as "foreign political systems" are reviewed and transformed in accordance to these seven functions. The nature of modernization as the general theme is "democratic modernization". Therefore, back then, democratization was already implied in "modernization". For example, in Social Origins of Dictatorship and Democracy, a well-known book on modernization, Barrington Moore focuses his study on the paths to democratization. However, in reality, development did not bring about modernization or democracy. Contrarily, it resulted in what Samuel P. Huntington terms as "political decay". Such a harsh result dealt a hefty blow 
to the optimistic liberals. The optimistic equation between development and democracy tends to be a hypothesis inconsistent with the history and reality of world politics. Structural functionalism, based on this hypothesis, is bound to be disfavored.

The structural functionalist paradigm is by and large believed to possess characteristics of non-historical West-centrism. Non-historical refers to coining theories without considering the diverse histories and cultures of each country, or even the historical process of Western politics itself. The seven functions are not inherent in American politics and are at most a result of its development over the course of history. Therefore, they are terminal "patterns", rather than a "political process" stemming from evolution in history. For example, in the 70-80 years after its independence, the United States was not a modern country. It became modernized as late as in the Civil War era. Even after that, a modern government had been absent as the institutions typical of a modern government, such as Food and Drug Administration, did not materialize until the progressive movement. What laws should be made on government functions? Who should enforce them? The United States indeed possesses its own prolonged history, but can non-Western countries achieve that progress in one step?

Additionally, like structural functionalism, many Western theories are regarded as "West-centric", but this is a generic way to label them. To be more specific, they constitute an "American model" or Western model that is utilized to explain and transform "foreign political systems". For example, recruitment entails "civic culture" and "political socialization", but the question remains, where is the United States" "civic culture" in its history of founding and growth? "Interest articulation" is nothing but another way of articulating interest group politics. What benefit did it bring even to the United States? "Interest aggregation" is nothing but multi-party competition. How did it perform in developing countries? "Rule making" and "rule application" are only a standard way of separating politics from administration. As we discussed above, the United States did not have a modern government, nor did their government had the function of "rule application", until the progressive movement took place. Almost all non-Western countries have a unified law making and application system. In short, structural functionalism measures "foreign political systems" with the "American model" with the purpose of transforming non-Western countries in accordance with the "American model" whose core is embedded in civil society, interest group politics, multi-party politics, and representative politics.

Therefore, structural functionalism comes across as a research approach in regional politics, but, in essence, it is a way to disseminate a political model. Failure is inevitable for any attempt to introduce the "American model" in non-Western countries against the historical conditions. The reason is simple. As we discussed above, all thinkers and philosophers, from the classical period to the modern times, bear in mind the social conditions of any regime. Structural functionalism is nonhistorical, indicating that the social conditions have ceased to be the focus of Western political scientists since the Cold War era. If a single model is enforced on a regime irrespective of the conditions, democratization or other kind of political change is bound to fail. A similar fate to that of structural functionalism occurred in the paradigm of transition that sought to promote democratization. 


\subsubsection{The Pro-democratization Paradigm of Transition and its End}

Modernization itself entails the intention to adopt the paradigm of transition as it is the transformation of a traditional society into a modern one. However, modernization research, like nation-building, involves too many variables, so it is not the same as the paradigm of transition. With the decline of modernization theory, American political scientists began to turn their research agenda of democratic transitions on non-Western countries. The most characteristic example is Woodrow Wilson International Center for Scholars' 7-year-long (1979-1986) research project on the transition of South America that resulted in a four-volume book. The last volume is a summary of its theories titled "Transitions from Authoritarian Rule: Tentative Conclusions about Uncertain Democracies”. In this volume, O’Donnell and Schmitter define "transition" as the evolution from one institution to another. To be more specific, "transition is delimited, on the one side, by the launch of the process of dissolution of an authoritarian regime and, on the other, by the installation of some form of democracy, the return to some form of authoritarian rule, or the emergence of a revolutionary alternative" (O’Donnell et al. 2012). Simply put, authoritarian rule, in its various forms, inevitably undergoes transitions either towards democracy or to other institutions, such as authoritarianism or revolution. Noticeably, such a conclusion is rather cautious as it remains uncertain if the authoritarian rule will transit to democracy. However, the propensity towards democratic transition is quite evident as the key issues of democratic transition, including liberation, democratization, and social equality, are discussed throughout the book. However, as the director of Woodrow Wilson International Center for Scholars wrote in the preface, since only successful transition is meaningful, it is a pity that the consolidation process of a regime is not touched upon in the book (O'Donnell et al. 2012). As a matter of fact, when this project was concluded, the third wave of democracy, as termed by Samuel P. Huntington, had not started yet. The only exception was the transition of the Ibérian Peninsula in 1974. During the third wave of democracy, Huntington defined the criterion of successful transition: Bi-partisan alternation typical of a Schumpeterian democracy. Following this, studies on democratic transition and consolidation exploded and their roadmap was that all countries would adopt representative democracy which, as Fukuyama wrote in The End of History and the Last Man, is "the final and best form of government for humanity". They believed that, irrespective of the social conditions, authoritarian rule has the potential to inevitably transit to competitive electoral and multi-party democracy. It was summarized by Thomas Carothers, Vice President for Studies at the Carnegie Endowment for International Peace, as "paradigm of transition": All authoritarian states will transition to democracy; the transition will be orderly; elections will be decisive; social conditions will no longer be important; and the process will conclude with democratic consolidation, or social solidarity, for the smooth running of the state (Carothers 2014).

The paradigm of transition is very sophisticated as a theory, but the realworld democratic transition has to deal with harsh conditions that even Philippe C. Schmitter, one of the pioneers in democratic transition research, had to admit in 2010: "Really existing democracy has been disappointing... most of the regime changes over the past 25 years have resulted in poor-quality regimes unworthy of 
the struggles and sacrifices that it cost to bring them about... such disenchantment is hardly restricted to new democracies. In the established ones as well, analogous 'morbidity symptoms' are rife... the striking ubiquity of these symptoms suggests that there may be something more generically deficient in democracy's institutions and practices" (Schmitter 2012). Thomas Carothers openly asserted about "the end of the transition paradigm."

Indeed, certain countries "borrowed" the electoral system but enforced "electoral authoritarianism" or "competitive authoritarianism" instead. Chinese experts attributed the country's endurance against the transition wave and subsequent growth to its "resilient authoritarianism". Whoever said that Hitler was only an exception in the history of electoral democracy did not know history well. Elections were interrelated with authoritarianism right from the outset. Napoléon III, for example, was elected for his authoritarian rule and reformed a republic into the Second Empire through referendum. Max Weber discussed this in his Economy and Society, where he strongly suggested that such elections work only to reinforce the authoritarian personality. It can be assumed that this might have been the initial discussion of "electoral authoritarianism". However, Schumpeter, Lipset, Dahl, and Giovanni Sartori asserted that electoral democracy is the only legitimate form of government. But when it resulted in politicians like Putin, people realized that, after the third wave of democracy, suffrage was mainly used to consolidate authoritarian rule. This happens to be the connection between electoral democracy and authoritarianism. Thus, deducing the first law of electoral democracy is a straightforward task. This law can be adopted to establish the legitimacy of both the democracy and the authoritarianism.

Had Professor Schmitter summarized the theories on democratic transition after the Arab Spring in 2011, he would have probably emphasized on the relationship between social conditions, including many inherent ones, and democracy. Mass democracy, as a form of modern politics, can be homogeneous, such as electoral democracy. However, cultural genes, as the most deeply rooted social condition (history and cultural heritage), tend to be highly resistant towards any transformation. Electoral democracy is predominantly organized through political parties, which are endorsed by diverse ethnic groups, religions, and by and large an unequal social structure. Needless to say, such electoral democracy can evolve into "partisan democracy". To maintain order in an electoral democracy, a series of conditions for homogeneity are required: National identity, shared faith, a roughly equal social structure, etc. (Yang 2014a, b, c). Otherwise, the Arab Spring would become the Arab Winter and the "color revolution" of Ukraine would only lead to civil wars and further division. Furthermore, as witnessed during the historical course, the various recent political conflicts around the world were directly related to democratization and the third wave of democracy fueled by the "clash of civilizations" (Yang 2014a, b, c). From this, we can deduce the second law of electoral democracy: Electoral democracy may augment the legitimacy of certain regimes in countries with homogeneous cultures but can also result in clashes between political systems with diverse cultures and within a single political system that possesses a diversified culture. To rephrase it, electoral democracy may not necessarily accomplish stability and peace. 
Whether it is structural functionalism advocating modernization research or studies of transition promoting democratic transition, the root cause of the problem is that they arrogantly presume that democratic regimes can work in an orderly manner and independent of specific social conditions. Practices guided by such theories are bound to fail. If the politics of Cold War that rephrased liberal oligarchy into theoretical liberal democracy was a "cultural discontinuity" deliberately created for the needs of war, placing the regime in a vacuum without regarding the intelligent legacy in history for the same purpose can be very well deemed as a rationalist regime-determinism. This is a betrayal of the classical political science and can only lead to self-deception. Such political studies were unable to make any contribution for the "highest good", and in fact, only directed one country after the other into despair. Reality reveals that there is no going back for the developing countries that transitioned from authoritarianism to "partisan democracy". It would be impossible for them to reconstruct good governance. The reason is simple: Partisan democracy is based on "cake-cutting", but developing countries, which are by and large backward, do not have any cake to cut. More importantly, most developing countries, especially the large ones, are all culturally heterogeneous and partisan democracy can only lead to and aggravate their domestic political conflicts. Since the WWI, none of the emerging developing countries have ever transformed into a developed one by virtue of partisan democracy. Transition practices in the non-Western countries and politics based on "universal values" resulted in the refugee crisis in Europe and Trump being elected the president of the United States marked the end of the proposition of "the end of history" based on the paradigm of transition. The current United States can no longer spearhead the transition campaign. The Trump administration had announced "Value Oriented Diplomacy" and the United States withdrew from the Paris Agreement that sought to confront global warming. Such events indicate that human values or "universal values" are meaningless to the United States, a tacit understanding exposed by Trump. In the past, the United States tended to conveniently label other countries as rogue states in accordance with its own values. As the United States acted without any regard for the shared values of the humanity or global security, mainstream American economists and media had to admit to it being a "rogue state" as well (Stiglitz 2017).

After the launch of the reform and opening-up campaign, the resumed Chinese political science principally followed the course of American political science; and its concepts, research paradigms, and methods were adulated by the Chinese scholars. However, the paradigms of American political science failed one after the other as they evolved from the European school focusing on states, to the "socialized" school born out of the behaviorist revolution, and to the current intellectual game disconnected from reality (including the American reality). ${ }^{2}$ What should Chinese political science do? As political science is one of the most "practical" social

\footnotetext{
2 The usually high-profile American political figures do not participate in any event of American Political Science Association and the US Congress canceled their already limited funding of the Association. For American politicians, American political science has become a purely intellectual game, a game of qualifiable models that has nothing to be with reality.
} 
sciences and China is an instrumental player in world politics, is Chinese political science not supposed to make more contributions? From being denied by the idolators to seeing the idolatry collapse on its own, China's ascent exposes the huge gap between factual history and theories, which signifies that now is the right time to develop new theories.

\section{Chinese Political Science in the Global Context}

Attributable to the Industrial Revolution, Western powers created a huge colonial system in the 19th century. "Reverse movements" against this liberal order gave rise to the world political system shaped by ideologies in the 20th century (Yang 2019). In less than a century, humans witnessed the failure of liberalism and the consequent rise of fascism, socialist movements, and national liberation movements. Such drastic changes were unprecedented in human history. Since the Second Industrial Revolution in the mid- $19^{\text {th }}$ century, China had been increasingly involved in world politics and Chinese politics appeared synchronous with the global politics. Therefore, political changes around the world would naturally influence the development of Chinese politics since China was incorporated into the global context.

In such turbulent times, China underwent "great changes unprecedented in the past 3000 years" (in the words of Li Hongzhang). Though they had to encounter the failure of the Opium War, Chinese elites were once confident about their culture. Zhang Zhidong, for example, came up with the strategy, "Chinese learning as the fundamental structure, Western learning for practical use", to guide the Selfstrengthening Movement. However, this confidence was shattered during the SinoJapanese War of 1894-1895 as China, once a great country, was defeated by Japan that had been learning its way from China. Empress Dowager Cixi's endorsement of the Boxers and the signing of the Boxer Protocol destroyed the reputation of the Qing government, and the framework of Chinese civilization was highly distrusted. In the early years of the Republic of China, the New Culture Movement marked the onset of a wave of wholly embracing Western culture and discarding the Chinese culture. In the words of Hao Chang, this is the "age of transition" for Chinese thoughts: "The so-called age of transition refers to the three decades from 1895 to 1925, a critical period of transition between traditions and modern thoughts" (Chang 1993). In these 30 years, traditional Chinese political ideology was dwarfed, or even demonized, and Western schools of philosophy were introduced into China, kickstarting the ongoing debate between Westernization and modernization among Chinese intellectuals. Not only were there discordant voices among the Chinese thinkers but there was also the debate over a practical political path between reformism and revolution. Even those in favor of the latter had to decide on the participants: Whether to rely on the industrialists, merchants, and landlords as Chiang Kai-shek did, or farmers and workers as Mao Zedong advocated. There was chaos in political and academic circles alike. Whether it was the Beiyang Government or the Nanking National Government, the students they sent abroad mostly ended up studying European and American politics or Western schools of political ideology imported by Japan. It was also a major college subject in that era. However, they neglected 
the critical defect of applying such ideology to Chinese politics. As there were conflicts among warlords, between warlords and Kuomintang, and between Kuomintang and the communists, not to mention the national crisis resulting from the Japanese invasion, explanations of state or government from Western political scientists could only be part of the "pure knowledge" for intellectuals. Contrarily, the revolutionary Marxist school of political ideology was not allowed in the class but was put into actual practice and emerged dominant over other approaches. However, in the postrevolutionary age, self-inflicted conflicts started again.

\subsection{Revolutionary Political Science Seeking Great Changes: Marxist Political Science and its Fate}

With the dissemination of Marxism in China, the Marxist school of political science was established in the country. In the 1920-1930s, five or six introductory books on this school were published (Wang 2008a, b). The most representative one is Deng Chumin's Introduction to Political Science published in 1928 (by Kunlun Bookstore). Deng Chumin proposed the sixfold system describing Marxist political science: Methodology, classes, state, government, political parties, and revolution. It is especially commendable that its methodology does not only follow the materialistic concept of history but also stresses the recognition of changes to the state in the political process. All the six parts were included in the line of research on theories of world politics at that time. For example, about government, apart from general theories, it covered the typology of government and classified government into parliamentary government, fascist autocracy, Soviet government, Chinese government, etc.; the section on political parties discussed bourgeoisie, proletarian, and Chinese parties, as well as the general characteristics of all the existing parties, especially partisan rivalry; in the section about revolution, it discussed bourgeoisie and the socialist revolutions and analyzed the history and prospect of Chinese revolution alike. Therefore, this "new school of political science", or the "strategist school of political science", was completely different from the other prevailing schools in the Republic of China that focused on the abstract theories on state. Deng Chumin wrote in the "Conclusion": "Science is not a pure game of theories. Political science is no exception. Sciences on laws of motion in the objective world serve our activities in the world and our practices... so I did not approach this line of political research as I would in the case of general political science, but as political or revolutionary strategies and tactics of politicians and revolutionists." (Deng 2011a, b). This approach to the "new political science" illustrates his insight into the nature of political theories: "For us, political theories are not only ideas, thoughts, truths, or theories, but they are also undeniable weapons and political strategies and tactics for social movements and political campaigns." (Deng 2011a, b). Therefore, it can be argued that, though "taking the Three People's Principles as the criteria" in his analyses of classes, state, government, political parties, and revolutions in China, Deng's "new political science" fully incorporated the mission of Marxist political studies and can be regarded as a "revolutionary school of political science" (Deng 2011a, b). 
"Revolutionary political science" seemed to have fulfilled its mission after China's victory of the New-Democratic Revolution. In fact, during the adjustment of disciplines and departments in 1952, political science, sociology, journalism, and jurisprudence were abolished, and social science was replaced by three other disciplines: Marxist philosophy, Marxist political economics, and scientific socialism. The last one, scientific socialism, is the one most associated with political science and covers classic authors and the history of international communist movements. Disciplinary and academic research was no longer required in real politics and economy. Or rather, what remained was only research about political activities and economic life, instead of politics and economics, ideology replaced social sciences. But this does not mean that the New China did not need political theories, however, they were only allowed to be discussed internally within the ruling group at that time. Taking class studies as an example, the development from Lenin's theory on the possession of the means of production to those on faith and bureaucracy gave rise to the conclusion on the presence of "pro-capitalism party members among those in power", rendering "continuous revolution" a necessary path to take. With one after the other political movement, based on "revolutionary political science", the political theory on "continuous revolution under proletarian dictatorship" was postulated. In reality, it became the guiding principle of the Cultural Revolution and was based on the aforementioned "new class theory".

In 1980, political science and the other social sciences resumed their status as disciplines in China. However, as the development of social sciences stagnated and political studies gave way to surging political movements in the previous ideologydominated 30 years, books on the introduction to political science as a revived discipline had to be written on the basis of textbooks on Marxist political science in the era of the Republic of China. As a result, in the first edition of Introduction to Political Science (Editiorial staff 1983) jointly compiled by 25 universities headed by Peking University, another section on nations was added to Deng's original five sections, completing the six-fold approach. This textbook covers all the theories proposed in the 1980s and its major content is derived from the Marxist classics.

The major principle of Marxist political science is upholding the people's dominant position, making it "people's political science" as opposed to "capitalist political science". It was a source of vitality for Marxist political science and the strongest call of that time. "Revolutionary political science" laid the foundation for people's dominant position institutionally, but to enforce it on an individual basis, "construction political science" was required, which made it essential to build a modern China. Therefore, in the entire 1980s, the theme of political science and other social sciences was modernization theories.

\subsection{Political Science for Nation-building: Dissemination and Research of Modernization Theories}

The Self-strengthening Movement marked the beginning of modernization in China and the Chinese government launched the campaign to accomplish "the four modernizations" (modernization of industry, agriculture, transportation, and national 
defense) in 1974. Therefore, modernization has long been an ideal for the Chinese people. The reform and opening-up campaign of 1978 kick started a new round of debates over modernization. At that time, it was a synonym of physical wealth and prosperity, and its political dimension was far from being the focus. After openingup, China came to realize that it lagged so behind the West that the whole society, instead of the just revived political science alone, was seeking modernization theories. The research subject of the 1980s was "how to achieve modernization". Since "modernization" was a research subject in Western political science in the 1950s-1970s, the abundant research results appeared quite tempting to the then barren Chinese academia.

In terms of disseminating modernization theories, several book series made undeniable contributions.

The first one is the "Toward the Future" series edited by Jin Guantao and published by Sichuan People's Publishing House. Seventy-four books were published under this series from 1984 to 1988 . They were either written by Chinese authors or translated into Chinese and covered the topics of social sciences and natural sciences, alike. Many classics on modernization and development were translated, including The Limits to Growth by the Club of Rome, Dynamics of Modernization by Cyril Black, Becoming Modern by Alex Inkeles, and Why Has Japan Succeeded? by Michio Morishima. Among the first research results from Chinese modernization studies, there were Towards National Modernization and The First Industrialized Society by Qian Chengdan, Western Bureaucratic System by Yang Baiqui et al., Evolution of Western Social Structure by Jin Guantao, Humans' Discoveries by Li Pingye, and Development Themes by Zhou Qiren et al. Noticeably, this book series was the first to inspire people to imagine and conceptualize the future or modernization, however, systematized modernization theories were yet to form.

The second book series is the "Yellow Books" published by Huaxia Publishing House (The 20th Century Collection). Most of the books in this collection are about research discoveries from Western modernization studies and they allowed Chinese scholars to have their first access to the approaches and paradigms of Western modernization research. The most influential ones are Social Origins of Dictatorship and Democracy by Barrington Moore, Political Order in Changing Societies by Samuel P. Huntington, No Easy Choice: Political Participation in Developing Countries by Samuel P. Huntington and Joan M. Nelson, A Systems Analysis of Political Life by David Easton, Political Sociology by Maurice Duverger, Politics and Administration by Frank J. Goodnow, etc. Chinese scholars, for the first time, realized how much Chinese political science lagged its Western counterpart.

The third book series is the "Yellow Books" published by Shanghai Translation Publishing House (Collection of Translated Contemporary Academic Works). Some of the classics on modernization research produced a great impact on the Chinese political science. Some of the included works were dominant throughout the entire 1990s and resulted in the prevalence of structural functionalism as a paradigm in China, including Comparative Politics: Systems, Process and Policy by Gabriel A. Almond and G. Bingham Powell Jr., and Modern Political Analysis by Robert A. Dahl, which inspired Chinese scholars to reflect on the typology of regime. Several other classical works on modernization research were published under its name in 
the 1990s, including Comparative Modernization by Cyril Black and Modernization: Re-discussing Theories and Practices by Samuel P. Huntington.

Perceptibly, the research findings from the modernization-themed agenda in the 1980s were primarily from historians, rather than political scientists. For example, Professor Luo Rongqu from the Center for Studies of World Modernization under Peking University posited the "unary and multi-threaded" historical view on modernization in his New Theories on Modernization and Qian Chengdan, professor of history from Peking University, produced a series of vital findings in his modernization studies. After accepting the modern Western research paradigm, Chinese political scientists did not focus a lot on Chinese political history, rather, they followed the "pragmatic" tradition of Confucianism and focused their research on Chinese politics after the reform and opening-up campaign. Research subjects in this period included one country with two systems, government functions, government independence from party influences, political democratization, etc. Some of the principal studies garnered much interest from the policy-makers and their findings were implemented as actual policies, such as studies of cadre system reforms (Wang 1987). Chinese political science started gaining recognition with respect to political significance as Professor Wang Huning, an outstanding scholar at the time, joined the central government in the 1990s and was later appointed as a party and state leader.

\subsection{The Theory of Regime Changed in Diversity Studies: The Political Science of Liberal Democracy}

In the 30 years following the 1980s, Chinese political scientists caught up with their Western counterparts in terms of research subjects but were still unable to receive recognition overseas for their findings. With the collapse of the socialist bloc, Fukuyama's The End of History became so impressive that a multitude of people still believe the representative democracy to be the best and final form of government for humanity. After 1990, although Chinese political science illustrated a diversifying trend based on the subject of "governance", one undeniable tendency was to put faith in the basic theories of liberal democracy. Under the influence of this basic tendency, vital and intricate modernization theories on nation-building became secondary to the simple regime modifications. It seemed that once the regime was reformed into liberal democracy, all the problems happened to be resolved automatically. This overwhelming tendency was synchronous and homogeneous to the international political trends.

Since 1990, Chinese political scientists have been increasingly open to other schools of ideology. In the 1980s, China finished translating classics on liberal 
Table 1 Subjects of the Papers Published in Chinese Academic Journals in 1990-2015

\begin{tabular}{|c|c|c|c|c|c|c|}
\hline & 1990-1995 & 1996-2000 & 2001-2005 & 2006-2010 & 2011-2015 & Total \\
\hline Democracy & 12,742 & 16,599 & 28,159 & 47,890 & 53,498 & 158,888 \\
\hline Democratization & 658 & 1047 & 2788 & 4303 & 4516 & 13,312 \\
\hline Civil society & 27 & 62 & 568 & 2580 & 2663 & 5900 \\
\hline Liberal democracy & 140 & 113 & 283 & 589 & 835 & 1960 \\
\hline Electoral democracy & 10 & 90 & 139 & 401 & 555 & 1195 \\
\hline Democratic transition & 2 & 13 & 33 & 168 & 351 & 567 \\
\hline Democratic consolidation & 2 & 3 & 10 & 54 & 82 & 151 \\
\hline People's democracy & 981 & 943 & 2140 & 3206 & 3001 & 10,271 \\
\hline Socialist democracy & 2419 & 4718 & 6538 & 7722 & 6127 & 27,514 \\
\hline $\begin{array}{l}\text { Socialist democracy with } \\
\text { Chinese characteristics }\end{array}$ & 107 & 180 & 222 & 629 & 803 & 1941 \\
\hline Chinese democracy & 5 & 11 & 23 & 181 & 220 & 440 \\
\hline Deliberative democracy & 72 & 241 & 257 & 1169 & 3978 & 5717 \\
\hline Grassroots democracy & 74 & 661 & 1145 & 2478 & 2407 & 6765 \\
\hline Intraparty democracy & 470 & 1157 & 1687 & 4847 & 3132 & 11,293 \\
\hline Governance democracy & 0 & 0 & 2 & 19 & 71 & 92 \\
\hline
\end{tabular}

Retrieved from CNKI Academic Journal Network Publishing Database (http://kns.cnki.net) through topic search (publication date from January 1, 1990, to December 31, 2015) from Social Sciences vol. $1 \& 2$ on June 5, 2017

Table 2 Citations of Schumpeter, Dahl, and Sartori in Chinese Academic Journals from 1990-2015

\begin{tabular}{lllllll}
\hline & $1990-1995$ & $1996-2000$ & $2001-2005$ & $2006-2010$ & 2011-2015 & Total \\
\hline Schumpeter & 96 & 409 & 1493 & 3089 & 3218 & 8305 \\
Dahl & 11 & 43 & 351 & 335 & 539 & 1279 \\
Sartori & 8 & 78 & 558 & 1202 & 1258 & 3104 \\
\hline
\end{tabular}

Retrieved from CNKI Academic Journal Network Publishing Database (http://kns.cnki.net) through cited references (publication date from January 1, 1990, to December 31, 2015) on June 5, 2017

political science. ${ }^{3}$ In the 1990 s, democracy research became dominant and liberal democracy governed Chinese political science (see Table 1).

Since the 1990s, neo-liberalism, or liberal democracy, has been a subject of keen interest for the majority of the Chinese publishing houses. No other keyword was comparable to "democracy" as at least 300 translated works on democracy were published, covering almost all the books with "democracy" in their titles. Consequently,

\footnotetext{
3 In the mid-1980s, the "Collection of Translated World Classics" published by the Commercial Press, including the major works of Locke, Hobbes, Montesquieu, Rousseau, American federalists, and John Stuart Mill, was released. The collection had an undeniable impact on the generation that grew up in the 1980s when China just opened up to the outside world and lacked intellectual resources. They were so influential that some of their readers are still stuck in the knowledge structure and ideas they represented in the 1980 s.
} 




Fig. 1 Trend of Political Science Papers on Liberal Democracy by Subject from 1990-2015

the theories of Schumpeter, Dahl, and Sartori nearly dominated all the debates over democracy in China (as shown in Table 2), and competitive or partisan election was regarded to be the essence of democracy. In other words, democracy was believed to follow only one model-Competitive or partisan democracy. Correspondingly, Chinese political science adopted a very internationalized research agenda and "democratic transition", "democratic consolidation", "civil society", "constitutional democracy", and other keywords became the chief topics of democracy research. As a result, liberty, democracy, and similar concepts occupied the moral high ground and studies reflecting on (let alone criticizing) them were often labeled as immoral (Fig. 1).

In the present era, people have to admit that countries seeking to transition in accordance with the indexes of Freedom House, an organization promoting freedom and democracy, are destined to doom. The power relations involved in nationbuilding are quite complicated. How can we fully account for them with "personal freedom" and "competitive election"? Moreover, as an "existence", state is equal to the people in the sense that it grows in the dimension of time. Therefore, it is impossible to ignore the time factor and apply "one universal solution" to the problems of all countries. China has a long pragmatic tradition throughout its history. It demonstrates that Freedom House is nothing but a political "cult". Similarly, the Democracy Index by the Economist Intelligence Unit (EIU) and the Democracy Index are all digital means to disseminate liberal democracy.

Around 2010, the Chinese people's concept of democracy became more intricate, or mature. Electoral democracy (formalistic democracy), which had dominated the Chinese academia for around 30 years (1980-2010), seemed to be under the risk of being replaced by "substantial democracy" (with governance and people's livelihood as criteria) and "deliberative democracy" (see Table 1 for data on "electoral democracy" and "deliberative democracy") (Huang 2016). The diversified understanding of democracy and its various forms demonstrated that the Chinese people were growing advanced in their knowledge of democracy (Yang et al. 2015).

Moreover, mainstream Chinese political science did not restrict itself to "democracy". Instead, it returned to the tradition of "stable governance" inherent and 
indispensable in the Chinese culture. This approach has proven remarkably fruitful and Chinese political scientists, thus, seem more fortunate than their foreign colleagues could ever be. Such a tradition made historical contributions to the political development of China, a fact that was evaded in the past. Hence, it is the time to reflect on that.

\section{Returning to the "Stable Governance" Tradition: Chinese Political Science Focused on State Governance Research}

As discussed in the beginning of this study, Chinese are born "believers in governance". Political economics serving state governance appeared in China as early as in the $8^{\text {th }}$ century BCE, when the Twenty-Four Histories were written. Most of their content is about state governance and they contain records of governance practices, as well as numerous governance theories. Due to their efforts, China ushered in one "golden age" after the other and became a 5000-year-old civilization. The Chinese civilization holds a great variety of innate and tested governance theories, including "unification", "bureaucracy", "world harmony", "world prosperity", "agriculture over commerce", "governance wisdom", and "people-centrism." It is for this reason that the whole community has kept its vitality intact despite the trials and hardships. Many Western thinkers cannot comprehend such an experience, as the dichotomous definition of "tradition-modernity" is not enough to elucidate the Chinese history. However, many people still prefer this outdated method even today.

Contemporary Chinese political science follows the "stable governance" tradition. Though western centrism was once too dominant, mainstream political science in Chinese universities revolves around the "state governance" and entails research about governance at various levels. It demonstrates that pragmatism is in the blood of the Chinese people. A precondition for doing governance research is that the researcher should keep a cautious and serious attitude towards prevailing concepts and ideas, instead of blindly accepting them.

\subsection{Exploring an Independent Discursive System of Political Science}

The 1980s and 1990s were an indispensable period of learning for Chinese political scientists. Without it, the Chinese people would be unable to understand their Western counterparts. However, due to the nature of social sciences, Chinese political science cannot be satisfied within the "period of apprenticeship". Social sciences entail the theorization of certain practices in a given period, of a country. By nature, they exist as local knowledge. We can find disastrous cases everywhere resulting from using such local knowledge in guiding the political development of another place. Therefore, in the 1990s, although Chinese political scientists were still learning from the West, some scholars began to criticize and reflect on the prevailing discourse in the Western political science. Such reflections eventually converged into a trend that cannot be neglected and effectuated the ultimate call of establishing a discursive system of independent and conscious theories. 
In the mid-1990s, Pan Wei criticized the "blind faith in democracy", defying the prevailing opinions of the world; whereas, Wang Shaoguang gave a full account of the problems of Western democracy research from the perspective of comparative political research (Pan 2003; Wang 2008a, b). Since 2010, the Chinese people's understanding of democracy has become increasingly mature as new insights into electoral democracy emerged. In some of my prior studies, I tried to demonstrate the indispensability of social conditions, including a series of "conditions of homogeneity", such as national identity, shared faith, and a roughly equal social structure. Other basic concepts related to democracy, such as civil society and legitimacy, were "re-interpreted" on this basis. Civil society, for example, can have completely different substance and political effects with diverse public opinions (Yang and Li 2014). It appears inconsistent with history or reality to regard the electoral mandate as the basis of the legitimacy of democracy; otherwise, there would not exist "electoral authoritarianism" or "competitive authoritarianism" (Yang 2016a, b, c, d). In his research, Zhang Fei' an tried to validate that in liberal democracy centered on electoral mandate, liberty practically replaces democracy and theories of liberal democracy are actually a socialist political trend (Zhang 2015).

Owing to this wave of reflective thought, Chinese people began to return to their own pragmatic tradition in the understanding of democracy and watched out for pro-establishment theories that could replace negative theories. The most important change was the change of direction in the theories of deliberative democracy as it became the most favored political development path by the government. This propelled a wave of deliberative democracy research and published papers on this subject soon surpassed those on liberal democracy in quantity (see Table 1 for the data). Among them, Lin Shangli's studies are the most universal ones. He believes that deliberative politics is the most deeply rooted concept in China's political tradition and thus, the most long-lived one (Lin 2003). In studies of China's policy-making process, Wang Shaoguang discovered a model based on consensus that constitutes the "consensus democracy" where consensus is attained through deliberation in the political process (Wang 2013; Yang 2017a, b). I believe that democracy based on deliberation and consensus is a "governable democracy" that can replace the ungovernable liberal democracy centering on partisan conflicts, and that only governable democracy is desirable (Yang 2013) It allows result-oriented "populist democracy" just as electoral democracy, as a model of practices, allows for value-oriented liberal democracy (Huang 2016). Wang Shaoguang termed "populist democracy" as "representative democracy" (Yang et al. 2015). The solution lies in a populist approach as a way of "reversed political participation".

The dispute over democracy models is propelled by the difference in mindsets: Westerners tend to value the form of regime more, whereas Chinese people are more engrossed in the political and governance principles. Ideologies and mindsets predicated on the governance principles naturally promote substantial democracy, rather than procedural democracy in a regime. In his comparative political analyses of several Asian countries, Fang Ning discovered that the general proposition for democratic progress is to hedge against political power with open rights. From this perspective, Chinese democracy has come a long way. Since about 2010, certain Chinese political scientists have disaffiliated from the Western politics of Cold War 
and successfully created an initial framework for an independent discourse system on democracy.

The Chinese political researchers have also built an effective independent democratic discourse system of governance. As innate "believers in governance", Chinese people tend to naturally be sensitive to "governance". In the early 1990s, the concept of "governance" which was proposed by economists of the World Bank, captured the attention of Chinese researchers quite rapidly. However, governance, as defined by the Westerners, was only a part of the ongoing trend and a synonym of "democratization" or "civil society". Its primary focus was on "denationalization" without discarding the theoretic framework of socio-centrism. Chinese people, instead, are innate believers of the concept of "state governance". Even before "the modernization of state governance system and capacity" was proposed at the $3^{\text {rd }}$ Plenary Session of the 18th CPC Central Committee in 2013, a multitude of researchers, including $\mathrm{Xu}$ Xianglin and I, were already reviewing the concept of state governance. Xu introduced the research paradigm of "state governance" that entails value, political identification, public policies, social governance, etc. (Xu, 2010). When "state governance" became an official term, its difference from the Western concept of governance was elucidated. As Wang Puqu enthusiastically reported, "State governance in socialist countries is, in nature, an organic combination of political rule and management, as well as one of the rules and management of political administration. Therefore, in the Marxist discourse system of state theories, "governance" is an organic combination of political rule and management for socialist countries". It acts as a reminder to avoid two cognitive deviations about state governance: One is that the Western notion of "governance" is not exactly applicable to China's goal of reinforcing reforms; and the other is that "governance" does not portray exclusiveness to contemporary Western political and management theories (Wang 2014). In the traditional Chinese context, political rule has always been a prerequisite for governance. Hence, it is strongly believed that the core of the state governance system remains in the balanced handling of the relationship amongst various powers of a state. In particular, it is imperative to effectively comprehend and acquire a strategic approach to the relationship between economic, military, ideological, and political powers. Based on this, I proposed the "general theories on state governance capacity" and identified its three major aspects, i.e., institutional inclusiveness, capacity for institutional integration, and capacity for policy enforcement. This is a set of governance theories in accordance with comparative political studies that are value-based, systematic, hierarchical, and asymmetrical (Yang 2017a, b). Currently, Chinese governance studies are developing on a large scale. Many universities have founded their own research institutions for analyzing "state governance", such as the state governance research centers or institutes at Peking University, Renmin University of China, Tsinghua University, and Huazhong University of Science and Technology. Additionally, the journal, State Governance Studies, was founded (Yang).

Contemporary pro-establishment political research is a form of brainstorming based on Chinese history and practices that evolved along with a dialog on "western centrism". Therefore, it is indeed a symbol of "political maturity" for contemporary China. Certain people assume that the pro-establishment theories are essentially in favor of the status quo. However, such elites and mainstream political theories only 
Table 3 Subjects of the Papers Published in Chinese Academic Journals from 1990-2015

\begin{tabular}{lllllll}
\hline & $1990-1995$ & $1996-2000$ & $2001-2005$ & $2006-2010$ & $2011-2015$ & Total \\
\hline Governance & 2731 & 4364 & 13,159 & 37,329 & 76,301 & 133,884 \\
State governance & 14 & 34 & 288 & 635 & 8873 & 9844 \\
Government governance & 3 & 23 & 481 & 1755 & 3530 & 5792 \\
Social governance & 10 & 24 & 357 & 1582 & 10,709 & 12,682 \\
Local governance & 4 & 5 & 79 & 460 & 1002 & 1550 \\
Grassroots governance & 0 & 5 & 54 & 527 & 3265 & 3851 \\
\hline
\end{tabular}

Retrieved from CNKI Academic Journal Network Publishing Database (http://kns.cnki.net) through topic search (publication date from January 1, 1990, to December 31, 2015) from Social Sciences vol. 1 \& 2 on June 26, 2017

come across as arrogant and self-abased because they prefer the path of transition to Western democracy that has been a failure in several cases, instead of preferring their existing regime that has made great progress in governance and seems to be on an upward path and has gained favor. In the past 30 years, the elites of many countries mistook coined concepts and conclusions for robust political beliefs and led their own country into ineffective governance and eventually crises. The global political situation in the past 30 years is a testimony that the Chinese experience is a major historically and politically significant contribution to the world, since Chinese institutions and practices are increasingly admired and consulted by other countries.

The current pro-establishment theoretical research focuses on the Chinese path or "the Chinese model". In the early twenty-first century, with the "Beijing Consensus", a group of Chinese scholars invented the "Chinese model" (Pan 2009; Zhang 2008; Ding 2011; Zheng 2011). It is believed that this model emphasizes on the hybrid democratic centralism and that its nearly century-old principles and institutions evolved from their prototype in the revolutionary period to the revised form in the first 30 years post the foundation of the PRC, and then to the current form since the launch of the reform and opening-up campaign. In this process, democracy and centralism function in a balanced manner (Yang and Qiao 2015).

\subsection{The Trend of Chinese Political Science Focused on "GOVERNANCE" research}

As discussed previously, governance research forms an instrumental part of Chinese political science and has been converted into a trend in recent years. In terms of governance, the quantity of research papers with keywords such as state governance, government governance, local governance, social governance, grassroots governance, etc., is almost comparable to those on democracy (see Table 3 for data). Hence, it can be interpreted that "democracy" and "governance" are the most vital themes of our time.

The data from Table 3 demonstrates that ever since the introduction of governance theories in China, research papers on this subject have been doubling every year and that the state governance research was at its pinnacle after the 3rd Plenary Session of the $18^{\text {th }}$ CPC Central Committee in 2013. The number of research papers 
with "state governance" as a keyword escalated suddenly from 545 in 2013 to 3780 in 2014, which amounts to three times the total number in 20 years from 1990 to 2010. Similarly, social governance research attained its peak in 2013 as well (as "social governance" replaced "social management" for the first time in the communique of the 3rd Plenary Session of the 18th CPC Central Committee). The number of research papers with "social governance" as a keyword grew from 709 in 2013 to 3782 in 2014, amounting for more than twice the total number in 20 years from 1990 to 2010. Government governance, grassroots governance, and local governance research has been reasonably progressing at a steady rate.

State-building theories and policy results. State governance is required to function under well-defined lines of authority; therefore, such research must adopt nationbuilding as a prerequisite. First, let's talk about social science theories on nationbuilding models. From a disciplinary perspective, state-building research falls under the category of historical sociology. Based on the state-building process of major countries, Western historical sociology proposed two sociological approaches: Socio-centrism and state-centrism. Nevertheless, neither of the two approaches can suitably explain the Chinese case. As the country was fragmented after the Revolution of 1911 and then reorganized by political parties, there ought to be a place for party-centrism in the nation-building paradigm (Yang, 2011). This concept has been widely recognized and implemented in the research practice of the CPC's history and comparative political research.

Now let's analyze the "structure-sequence" approach to state-building. Prevailing state theories mostly take into account the dichotomous classification of state and society as a basic prerequisite. In this classification, "state" is well-defined, but "society" is not. Is it possible to ascribe the same social attribute to Alibaba, with its market value of trillions, and an individual bun-seller? Classifying large corporations as a part of the "society" will only facilitate their abduction of national interests and exploitation of the public. Zeng Yi considers that modern states possess a basic triple structure comprising of "political power, capital power, and social power" (Zeng 2014). Furthermore, these three are related in a transient manner. Simply put, political power, which initially came into being as state power, protects and precedes the capital power, which is then followed by social power. Even for the relationship of political powers, basic personal rights (e.g., property rights and personal rights), political rights represented by elections, and social rights focusing on social insurance, are unattainable simultaneously. Developed and developing countries may exhibit diverse combinations and sequences, but the latter tend to more likely be subject to and influenced by the former and thereby suffer from modernization issues (Zeng 2012). This is a finding from comparative political research, as well as a realization in the research of the Western history of political ideology. Chinese scholars' understanding of the intricacy of nation-building in terms of structure and temporality is in no way inferior to the Westerners' order-based theories, including Fukuyama's "strong state, the rule of law, and democratic accountability".

Among the studies of the relationship between political powers that concerns state building, the most significant one for policymaking is probably The Report on China's State Capacity by $\mathrm{Hu}$ and Wang (1993). It greatly assisted the reshaping of the country's fiscal and taxing system, the most critical subject for central-local 
relations. In the context of democratization's prevailing presence and amid the trend of "denationalization" in international social sciences currently, a demand for the improvement of government capacity and potency was a refreshing approach (Wang 2002).

Government governance research. The core of state governance tends to be the government governance, which is mainly composed of the plausibility of the government's own structure, the transformation and optimization of government functions, scientific policy-making, and scientific government industrial policies. First, in terms of government or function types, the Chinese government has been redefined as a "service-oriented government", instead of a "corporate" one, as it was in the 1990s. This is a contribution from administrative management science. Nonetheless, this definition proved baffling in practice or even counterproductive in ascertaining the relationship between the state power and the market. As even individual stall-keepers have to apply to the government for "license", a "service-oriented government" alone is evidently not enough to deal with the omnipresent government intervention. Therefore, based on the decision taken at the $3^{\text {rd }}$ Plenary Session of the $18^{\text {th }}$ CPC Central Committee to launch the reform, multiple scholars hypothesized the notion of "competent limited government": The state must possess competence and power, but that power must remain within certain boundaries and its use should be restricted (Yang 2014a, b, c).

At the Chinese Academy of Social Sciences, a research institute for state policies, the research team in the Institute of Political Science headed by Fang Ning has, for a long time, been focusing on the government's method of demand and supply by conducting systematic social surveys and building survey bases. Their research reports are of great referential value for the development of state policies. Thus, it is clear that the Institute of Political Science has been conducting inclusive and versatile research on government governance.

For policy-making research, Chinese political science is challenging the conundrum of the process through case studies. Understanding the policy-making process appears instrumental in deciphering the nature of a country's regime. To effectively comprehend this process, one vital prerequisite is to understand the policy-making system. Zhou Guanghui deems that since the launch of the reform and opening-up campaign, the policy-making system reform has illustrated the following trends: From individualized to democratic policy-making, from experience-based to scientifically executed policy-making, from highly centralized to decentralized policy-makers, from enclosed to open policy-making, from passive participating to proactive participating policy-makers, and from non-institutionalized to institutionalized policy-making. This transition allowed the Chinese government to successfully deal with the numerous challenges that arose from the rapid economic and social changes (Zhou 2011). Based on the research of the policy-making process involved in the healthcare system reform and the 13th Five-Year Plan, Wang Shaoguang and Fan Peng reported that China's policymaking process is a fully "consensus-based policy-making" process. (Wang and Fan 2013). In his investigation into state, departmental, and local decision-making, Yang Guangbin discovered that China abides by a policy-making process that is typical of "consensus democracy" (Yang 2017a, b). Ma Jun introduced a new 
approach known as "budgetary politics" and examined the budgetary political process, especially the "black box" of provincial budgetary politics (Ma 2011). This approach is certainly conducive to China's budgetary democratization, while the democracy of political process, or administrative democracy, happens to be the actual key to political democracy.

In his research of the functions of the Chinese government, Zhu Guanglei and his team managed to attain a series of results with clear significance to policy-making. In his words, "the super-ministry system is not a cure-all", a clear warning to the once-dominant super-ministry system reform (Zhu 2008). In his research on the most rational proportion of civil servants to the population, he pointed out that China's issue does not lie in the staff size of civil servants, but in the international functions and structure of the civil servant system (Zhu and Li 2008). In terms of government functions, Zhu advised to emphasize on the government functions in management and service domains and "socialize" its political acts, which should be internalized as one of the most basic governance principles of China and a holistic approach that needs to be incorporated in all the aspects of governmental work, instead of a generic strategic adjustment (Zhu and Yu 2015).

In terms of research on specific government policies, Peking University undoubtedly ranks the best. The "State Governance Research Collection" edited by Wang Puqu entails research findings from policy-making in diverse fields, including administrative petitions, household system reforms, river valley water pollution control, and compulsory education. Among the studies on industrial policies, one of the most important studies on policy-making is Lu Feng's study on the success of high-speed rail and large aircraft projects and the failure of the automotive market (Lu 2004, 2005a, b, 2013). Such studies based on specific policies tend to be highly beneficial in understanding the Chinese policy-making path, especially the Chinese model.

Local governance and social governance research. "Local" is an ambiguous concept in the Chinese context as it can be used to describe all governments below the central level, or only those under the provincial government (whose jurisdiction covers the county, district, and municipal governments under it). Consequently, in China, local governance is a generic concept that covers both urban and social governance.

Social governance in local governance. Based on the notion of incremental reform, Yu Keping hypothesized the concept of "incremental democracy". Based on several foreign governance theories, he introduced the concept of "good governance", whose basic characteristics are participation, honesty, transparency, interaction, accountability, rule of law, and legitimacy (Yu 2005). The subject of governance ought to be the "society", hence, "good governance" can be deemed as a social governance theory (Yu 2001; Yu et al. 2002). Based on this assumption, the research team at the Central Compilation and Translation Bureau released a system of good governance indexes, which is generally believed to be highly analogous to that of the World Bank (Yu 2009). Based on social governance theories, Yu Keping and He Zengke conducted a decade-long "Local Government Innovation Project" to evaluate the innovative acts of local governments. They believed that local governments 
tend to demonstrate a striking urge to innovate in the first five years, but then cease to conduct innovative projects in the subsequent five years.

The Peking University Research Center for Contemporary China has been a leader in quantitative political studies in China. It has, for a long time, been focusing on surveys of civic awareness in China, which emerged as indispensable data for research on social and government governance (Shen et al. 2009).

Urban governance in local governance. The most representative research was conducted by $\mathrm{Yu}$ Jianxing and his team who, taking advantage of their location, evaluated the relationship among the governance model, governments, and chambers of commerce (industrial associations) of the urban districts of Zhejiang province (Yu 2011; Yu and Song 2009). Their research signifies real-life cases and theoretical inspirations for understanding the political and economic relations at the grassroots level in the developed areas of China.

Grassroots governance and rural governance. Rural governance research, represented by $\mathrm{Xu}$ Yong and his team, has been formulated into the "Central China School" (Central China Rural School). First, their contribution is established in two aspects: Research approach and political development. In terms of research approach, their research on rural issues since the 1990s propelled the top-down transition of Chinese political science as "society" became an important research subject in the discipline. Based on his long-term research on farmers, Xu Yong proposed the concept of "peasant rationality" to change the entrenched stereotype of farmers, providing a much-needed perspective for the understanding of the "Chinese miracle" (Xu 2010). In terms of political development, the results from grassroots democratic governance research manifest in the form of "constitutionalization", which means that grassroots democracy has been defined as a fundamental political institution in China, along with the multi-party cooperative system under the CPC's leadership and the system of regional ethnic autonomy. Secondly, the "Central China School" has had a lucid stance towards land privatization, a political conclusion drawn from historical analysis. Finally, in terms of the land rights confirmation system reform, it was discovered that the joint-stock companies with pooling of land share, in the Pearl River Delta region, were practically transformed into powerful interest groups who obstructed the progress of urbanization with soaring land prices, which led to the Wukan protests (He 2017). It would not be wrong to say that to truly understand the countryside, Chinese political scientists must rely on the research findings of the "Central China School."

$\mathrm{CPC}$ research and state governance. In the research of state governance at any level or in any field in China, the CPC appears as a mandatory research subject. Therefore, in terms of research approach, the once dominant dichotomous definition of "state-society" ought to be replaced by the trichotomy of "political partystate-society". In my opinion, as China is a party-state where one party takes on the role of governance, trichotomy is only a claim or statement that will hardly contribute to any breakthrough. As for the nature of the $\mathrm{CPC}$, the official claim remains that it has made the transition from a revolutionary party to a governing party. Chen 
Mingming, instead, proposed the three-stage theory: "Revolutionary party-ruling party-governing party" (Chen 2011). These were some of the prominent academic analyses of the CPC. Based on what happened to the Soviet Communist Party, the CPC, a long follower of its model, was once believed to meet the same fate. Thus, many researchers began to advocate the so-called "transition" research. The birth and growth of the CPC would not have been possible without the Third International founded and led by Vladimir Lenin, and the two indeed had some common traits. However, even parties of the same nature cannot exist independent of their own historical and cultural contexts, so there are some inevitable differences. The differences must be the focus of our research. To Pan Wei, the most fundamental characteristic of the CPC happens to be its "affinity to the people". The key to realize this is to eliminate the hierarchy and further integrate the party branches into the people, so that they can provide them with "daily services". A hierarchical party, instead, is better at completing "large projects" (Pan 2012, 2017). We should not try to understand the CPC functioning based on Western theories of political parties, nor can we explain its particularities with Marxist theories on the same. Therefore, it is required of Chinese political scientists to "liberate their minds" and revitalize their understanding of its nature and relationship with the state. Otherwise, the intrinsic mechanism of China's governance achievements would be incomprehensible. The "party-centrism" that we discussed previously was a crucial preliminary result of similar research.

\subsection{Summary: Chinese Political Science as a Pro-establishment Force}

By reviewing Chinese political science through the spectrum of state governance alone, we found that it has already become a significant force in national political development. Mainstream research is pro-establishment, rather than "anti-establishment", as it is believed to be. This is a remarkable "finding". Politics and academic research must share a good interactive relationship and mutual trust; otherwise, the development of a ruling class and the discipline would be compromised. Personally, I believe that Chinese political scientists should play a better role as a pro-establishment force and learn from their American colleagues in this respect. They can respect relevant research paradigms, such as the one focusing on state governance, while ascertaining the nature of the specific society where the political research was derived from. ${ }^{4}$ This should be a prerequisite and the foundation for state governance research.

\footnotetext{
${ }^{4}$ Political science is a strongly conceptual discipline, so naturally there are disputes and difference of opinions among researchers. When he was appointed the president of the American Political Science Association in 1964, David Truman pointed out that political scientists should drop their differences and follow a common research paradigm just as economists chose to follow the rational choice theory, so as to enhance the development of this discipline. They did precisely that, which led to the dominant position of structural functionalism in American political science for 20 years.
} 


\section{Conclusion: Studying a Real "Society" and Building Applicable Governance Theories}

Notions and concepts are the roadmap for people's understanding of the world. In a way, the panorama of human civilization is a result of assembling the notions as if they were pieces of a puzzle or connecting concepts. Nonetheless, many theories are based on local experiences and become dominant only because they stem from powerful countries. Such theories may not represent the universal truth. In that sense, for advanced state governance research, we ought to revitalize our understanding of "civilization" and realize that its basic structure is comprised of language, religion, and social nature. For this study, "social nature" is a quantifiable variable. It is imperative to reconsider the nature of each "society", because in prevailing theories of state-society relationship, "state is a necessary evil", which means state is essentially evil, whereas "society" is essentially good and "civil society" even better. However, ironically, during the Industrial Revolution when thinkers claimed state was evil, it was precisely the state that protected the disadvantaged, while the society was sabotaged by capital power. Without such protection, farmers and the lower class would have been even more miserable. Social autonomy (or, in Abraham Lincoln's words, a country of the people, by the people, for the people) should have been a proposition for an agricultural society and has been the form of the rural society "ruled by the people" in ancient China, where the imperial power never spread its reach to the county level. In an industrial society, the "rule by the people" evolved into the "rule by capital power", which was powerful enough to even dominate over state power. Many people take "good society and evil state" as a prerequisite, irrespective of context or the temporal and geographical dimensions of the concept. It is not a very sound viewpoint to be considered in academic research. Comparative studies reveal that societies are inherently good or evil, as different countries have societies of vastly different nature. Therefore, theories based on a coined abstract concept of society (e.g., civil society) cannot be implemented and accepted directly as a universal truth, or to guide nation-building, state governance, and the handling of statesociety relationship. It would only result in completely distinctive scenarios or even chaos.

When writing Discovering "Society" and Building Governable Governance Theories, I found that social autonomy based on social equality is a rare phenomenon in the world. The American society has become one of the typical interest groups and its regime, one of oligarchy; South America was termed as praetorian society by Huntington; Africa is what Joel S. Migdal called "a strong society"; the Indian society is still based on the caste system; the Middle East is an Islamic society. In these societies, what good can it do to directly apply the hypothetical governance solution based on civil society, or one that is pro-individualism or socio-centric? Whose autonomy is it? How can it avoid unrestricted privilege? Can it be consistent with the hypothesis of "civil society"?

In the aforementioned types of societies, Islamic society appears typically equal, but it evidently is not a civil society. Other societies are essentially unequal, 
although equality is the basis of civil society. The various organizations in unequal societies, rather than civil organizations, are not so different from the various social groups that once existed in the history of their communities, such as various social organizations that were born in the Middle Ages and lasted for thousands of years in Europe. None of them is a so-called civil society. The American society of interest groups and the resulting state-society relationship are what they themselves claim as "social corporatism" (how can any society be corporate? Otherwise, there would not be a "veto-based regime"). Praetorian, strong, or castebased societies are not "social corporatist" because the state cannot be incorporate, a phenomenon called "social separatism". How is this form of society related to civil society? Interestingly, Islamic societies are usually equal, but they are not what the Westerners call "civil communities" based on mutual compromise and respect. Contrarily, by and large their members tend to be uncompromising and extremists. Therefore, how can such countries be governed effectively if coined civil society theories (or governance theories) are applied in the various versions of non-Western society? The "social separatism" in these countries has already led to their "about-to-collapse state". If such organizations progress even further, it can only result in a treacherous political situation ("privatized society") in the name of good concepts ("civil society"). Moreover, they would acquire more power against the state which would, in turn, become more fragmented. This is the fundamental reason why the development theories, including governance theories, since the WWII failed. Furthermore, in history, well-developed civil groups once helped create conditions for the emergence of fascism, as both Fascist Italy and Nazi Germany were born out of active social groups. This indicates that even in Western societies, social groups are a double-edged sword: They can either reinforce democracy or result in anti-democratic trends. They should be regarded as a neutral political variable (dependent variable) that can be both good and evil, depending on their political environment (Berman 1997). Undoubtedly, this is a challenge, but one that reflects the factual historical scenario.

Therefore, based on our understanding of the nature of society, we believe that social groups are not an "independent variable". The nature of society, however, is an unchangeable "independent variable" as it establishes that corporatism is not the same as civil society. This is not to encourage people to study and enhance social autonomy. Rather, we should first understand the nature of a given society in any case as no force, however, powerful it is, can shape the society as it would like to. Once chaos arises out of inappropriate "autonomy", the only solution that remains is to rely on the state, rather than the so-called "civil society". Therefore, what we require more than anything are the theories that can aid in the enhancement of the state governance capacity (see Yang 2017a, b).

As China is further progressing in its Belt and Road Initiative, the biggest challenge it faces in the process is to deal with the issues in societies with "social separatism" as their major characteristic. For example, the HSR project (Jakarta-Bandung) was stalled because of the private land ownership system, disputes between local forces, and fragmented government power. The central government of Indonesia could do nothing other than watch President Jokowi's infrastructure project fail (Liu 2017). Without studying the nature of non-Western societies, it would be impossible 
to find a precisely suitable solution for the same or proceed with the Belt and Road Initiative. Hence, studying the nature of society as the basis of social institutions is not only a necessity for state governance theories but also a strategic mission for global governance. Political science is deemed a discipline for both the state and political governance. The misuse of "good concepts" without proper analysis is not only a waste of academic resources but also tends to induce political damage and a risk to the state as well as global governance.

\section{Declarations}

Conflict of interest All authors declare that they have no conflict of interest.

Ethical statement I certify that this manuscript is original and has not been published and will not be submitted elsewhere for publication.

Open Access This article is licensed under a Creative Commons Attribution 4.0 International License, which permits use, sharing, adaptation, distribution and reproduction in any medium or format, as long as you give appropriate credit to the original author(s) and the source, provide a link to the Creative Commons licence, and indicate if changes were made. The images or other third party material in this article are included in the article's Creative Commons licence, unless indicated otherwise in a credit line to the material. If material is not included in the article's Creative Commons licence and your intended use is not permitted by statutory regulation or exceeds the permitted use, you will need to obtain permission directly from the copyright holder. To view a copy of this licence, visit http://creativecommons.org/licen ses/by/4.0/.

\section{References}

Almond, G.A. et al. 2012. The Politics of the Developing Areas. Ren, Xiaojin, et al., trans. Shanghai: Shanghai People's Publishing House, pp. 1-2.

Berman, H. 1997. Civil Society and the Collapse of the The Weima Republic. World Politics 49: 401-429.

Carothers, T. 2014. The End of the Transition Paradigm, in: Review of Comparative Politics (vol. 2). Yang, Guangbin, ed. China Social Science Press.

Chang, Hao. 1993. Democratic Ideas in Modern China amid Transition. Twenty-First Century 8: 18.

Chen, M. 2011. Revolution, Rule and Governance: Revisiting the Old Dispute over the Two Propositions for Party Reform. Social Science Research 4: 5-12.

Chua, A. 2014. World on Fire: How Exporting Free Market Democracy Breeds Ethnic Hatred and Global Instability. Liu, Huaishao, trans. China University of Political Science and Law Pres, p. 227

Deng, C. 2011. Introduction to the New Political Science. Commercial Press, pp. 402-403.

Deng, C. 2011. Preface, in: Introduction to the New Political Science. Commercial Press, p. 2.

Ding, X. 2011. The Dispute over the Chinese Model. Social Sciences Academic Press.

Editiorial staff. 1983. Introduction to Political Science. Peking University Press.

Friedman, T.L. 2001.Today's new Quiz. New York Times. November 11, A21.

He, X. 2017. The Reform of Collective Property Rights Institution in Rural Areas and Lessons from Wukan Protests. Administrative Tribune 3: 12-17.

Hegel, G.W.F. 2009. The Philosophy of History. New York: Dover Publications.

Hu, A. and Wang S. 1993. Report on China's State Capacity. Liaoning People's Publishing House.

Huang, C. 2016. From "People's Democracy" to the "Chinese Model": Evolution of Democratic Ideas in Contemporary China (1978-2008). Ph.D. Dissertation. Renmin University of China.

Lin, S. 2003. Deliberative Politics: A Reflection on the Development of Democracy in China. Academic Monthly 4: 19-25. 
Lipset, S.M. 2011. Political Man: The Social Bases of Politics. Zhang, Shaozong et al., trans. Shanghai Century Publishing Group, pp. 49-50.

Liu, T. 2017. An Analysis of the Stranded Indonesian HSR Project. MA Dissertation. Yang, Guangbin, supervisor. Renmin University of China.

Lu, F. 2004. Creating China's Own Automobiles. Business Weekly 6: 25-30.

Lu, F. 2005a. Strategic Thinking on the Development of the Chinese Aircraft Industry. China Soft Science 4: $10-16$.

Lu, F. 2005b. Y-10 Failed Because of China's Aviation Management System. China Reform 4: 53-54.

Lu, F. 2013. Solving the Mystery of High-speed Rail: Tracing back to the Origin of China's HSR Technology. Outlook Weekly 48: 30-32.

Ma, J. 2011. The Public Budgetary Reform of China. Economic Science Press.

Macridis, J., and R. Cox. 1953. Research on Comparative Politics: Seminar Report. American Political Science Review 47 (3): 641-657.

Mann, M. (USA). 2015. The Dark Side of Democracy. Yan, Chunsong, trans. Central Compilation and Translation Press.

O'Donnell, G. and Philippe C.S. 2012. Transitions from Authoritarian Rule: Tentative Conclusions About Uncertain Democracies. Jing, Wei and Chai Shaojin, trans. New Star Press, pp. 5-6.

Pan, W. 2012. A "New Path" to Being People-oriented for the CPC. People's Tribune: Frontiers 2: 66-73.

Pan, Wei. 2003. Rule of Law and the "Democracy Myth". Hong Kong Press for Social Sciences Ltd.

Pan, W. 2009. The Chinese Model: Interpreting the 60 Years of the People's Republic of China. Central Compilation and Translation Press.

Pan, W. 2017. Faith in the People: The Communist Party of China and the Chinese Political Tradition. China Renmin University Press.

Potter, G.R., ed. 1999. The New Cambridge Modern History: Volume 1, The Renaissance 1493-1520. Beijing: China Social Sciences Press, p. 1.

Rothbard, M. 2016. Economic Thought before Adam Smith: An Austrian Perspective on the History of Economic Thought (vol. 1). Zhang, Fenglin et al., trans. Beijing: Commercial Press, p. 29, pp. 31-32, p. 37.

Saunders, F.S. 2002. The Cultural Cold War: The CIA and the World of Arts and Letters. World Culture Books, pp. 5 \& 105 .

Schmitt, C. [German]. 2004. History of Thoughts on Today's Parliamentary System, in: Schmitt, Carl. Feng. Political Romanticism. Keli and Liu Feng, trans. Shanghai: Shanghai People's Publishing House, p. 165.

Schmitter, P.C. 2012. Twenty-Five Years, Fifteen Findings, in: Transitions from Authoritarian Rule: Tentative Conclusions about Uncertain Democracies, O'Donnell, Guillermo and Philippe C. Schmitter, eds. Jing, Wei and Chai Shaojin, trans. New Star Press, pp. 106-107.

Shen, M. et al. 2009. Survey Report on the Chinese People's Civic Awareness (2008). Social Sciences Academic Press.

Stiglitz, J. 2017. Trump's reneging on Paris climate deal turns the US into a rogue state. New York Times, March 6.

Wang, S. 2002. Effective Government and Democracy. Strategy and Management 6: 89-101.

Wang, P. 2014. A Comprehensive and In-depth Approach to the General Objective of Deepening the Reform in an All-round Way. Social Sciences in Chinese Higher Education Institutions 1: 4-18.

Wang, S. and Fan P. 2013. Consensus-based Policymaking in China: Introduction and Adjustment. China Renmin University Press.

Wang, G. 2008. A Discussion of the Newly Founded Chinese Marxist Political Science. CASS Journal of Political Science 3.

Wang, S. 2008. Four Lectures on Democracy. SDX Joint Publishing Company.

Wang, S. 2013. Consensus-based Policymaking in China. China Renmin University Press.

Wang. Huning. 1987. New Trends in Chinese Political Studies (1980-1986). CASS Journal of Political Science 2 .

Wong, R.B. (USA). 2016. China Transformed: Historical Change and the Limits of European Experience. Li, Bochong and Lian Lingling, trans. Suzhou: Jiangsu People's Publishing House, p. 77, p. 86.

Xu, Y. 2010. Expansion of Peasant Rationality: An Analysis of the Creators of the "Chinese Miracle" to Challenge Existing Theories and Propose a New Analytical Approach. Social Sciences in China 1: $103-118$.

Yang, G. 2000. Origin of the Cold War and Ideology. Teaching and Research 3: 29-34. 
Yang, G. 2014a. A List of Political Reforms for the Construction of a "Competence Limited Government": How to Understand "State Governance System and Capacity Modernization." Research of Administration Science 1: 33-36.

Yang, G. 2014b. Democracy and World Political Conflicts. Academics 8: 5-34.

Yang, G. 2016c. Misuse and Re-interpretation of Legitimacy. CASS Journal of Political Science 2: 2-19.

Yang, G. 2016d. "Universal Values" in Liberal Democracy Are Signs of the Arrogance of the West. Qiushi 19: 56-58.

Yang, G. 2017b. General Theories of State Governance Capacity. Teaching and Research 1: 3-22.

Yang, G. 2019. Political Thoughts: A Research Unit on World Political Changes. World Economics and Politics 19: 24-40.

Yang, G. and Li, N. 2014. "Public Opnions" in a Civil Society and Quality of Democracy. Journal of Henan University (Social Science) 3

Yang, G. 2011. Approaches to Institutional Changes and Their Significance in Social Sciences: Socio-centrism, State-centrism, and Party-centrism, in: Yang, Guangbin. 2011. States and Institutions in Political Changes. Central Compilation and Translation Press, pp. 182-243.

Yang, G. 2013. Beyond Liberal Democracy: General Theories of Governance Democracy. Social Sciences Abroad 4.

Yang, G. 2014. Falsification of Several Prevailing Propositions on Democratization. Beijing Daily: Theory Weekly, March 14.

Yang, G. 2016. Basal Body of Chinese Civilization: Understanding the Ontology of China's Future. People's Tribune 15 (58-61).

Yang, G. 2016. State Governance Studies (semi-annual). China Social Sciences Press.

Yang, G. 2017. Consensus Democracy in the Policy-making Process of China. Social Science Research 2.

Yang, G. et al. 2015. Chinese Democracy: Trajectories and Trends (1978-2020). China Social Science Press.

Yu, K. 2001. The Rise of Civil Society and the Good Governance of Government. China Reform 6: 38-39.

Yu, J. 2011. Let the Society Run: A Case Study of the Social Development in Haishu District. Ningbo City: China Renmin University Press.

Yu, K. 2005. Incremental Democracy and Good Governance. Social Sciences Academic Press.

Yu, Keping, ed. 2009. State Governance Evaluation: China and the World. Central Compilation and Translation Press.

Yu, K. et al. 2002. The Rise of Civil Society in China and Governance Changes. Social Sciences Academic Press.

Zeng, Y. 2012. Meaning of "Modern State" and the Internal Tension in Its Construction. Journal of Renmin University of China 3: 119-126.

Zeng, Yi. 2014. Modern Nation-building Theories: From Two-dimensional to Three-dimensional. Fudan Journal 6: 161-169.

Zhang, W. 2008. A Summary of the Chinese Model. People's Tribune 24: 22.

Zhang, F. 2015. Democracy Dissolved by Liberalism. China Social Science Press.

Zheng, Y. 2011. The Chinese Model: Experience and Predicament. Zhejiang People's Publishing House.

Zhou, G. 2011. The Formation and Reforms of Policy-making System in Contemporary China. Social Sciences in China 3: 101-120.

Zhu, G. 2008. "Super-ministry System” Is Not a Cure-all. Liluncankao 5: 48-49.

Zhu, G., and Y. Dan. 2015. On the Socialization of Political Acts. Tianjin Social Sciences 1: 92-98.

Zhu, G. and Li, L. 2008. A Preliminary Discussion of the Most Appropriate Proportion of Civil Servants to the Population. China Public Administration, pp. 68-74.

Guangbin Yang Ph.D., distinguished professor of political science and dean of School of International Studies at Renmin University of China, Changjiang Scholor distinguished professor, founder of Chinese Political Science, and World Politics Studies, vice president of Chinese Political Science Association. His areas of study include political science theories and methods, comparative politics, world politics, contemporary Chinese politics and government, Chinese political economy and international relations. He has authored and edited more than 10 books and published more than 100 papers in the above areas. 